\title{
The direct effect of aerosols on solar radiation over the broader Mediterranean basin
}

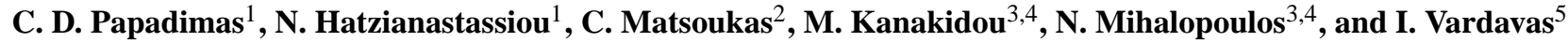 \\ ${ }^{1}$ Laboratory of Meteorology, Department of Physics, University of Ioannina, 45110 Ioannina, Greece \\ ${ }^{2}$ Department of Environment, University of the Aegean, 81100 Mytilene, Greece \\ ${ }^{3}$ Environmental Chemical Processes Laboratory, Department of Chemistry, University of Crete, P.O. Box 2208, 71003 \\ Heraklion, Crete, Greece \\ ${ }^{4}$ Institute of Chemical Engineering and High Temperature Chemical Processes (ICE-HT), Foundation for Research and \\ Technology Hellas (FORTH), Patras, 26504, Greece \\ ${ }^{5}$ Department of Physics, University of Crete, 71110 Heraklion, Crete, Greece
}

Correspondence to: N. Hatzianastassiou (nhatzian@cc.uoi.gr)

Received: 22 August 2011 - Published in Atmos. Chem. Phys. Discuss.: 8 November 2011

Revised: 3 July 2012 - Accepted: 16 July 2012 - Published: 7 August 2012

\begin{abstract}
For the first time, the direct radiative effect (DRE) of aerosols on solar radiation is computed over the entire Mediterranean basin, one of the most climatically sensitive world regions, using a deterministic spectral radiation transfer model (RTM). The DRE effects on the outgoing shortwave radiation at the top of atmosphere (TOA), DRE $\mathrm{T}_{\mathrm{TOA}}$, on the absorption of solar radiation in the atmospheric column, $\mathrm{DRE}_{\mathrm{atm}}$, and on the downward and absorbed surface solar radiation (SSR), DRE surf $_{\text {and }} \mathrm{DRE}_{\text {netsurf }}$, respectively, are computed separately. The model uses input data for the period 2000-2007 for various surface and atmospheric parameters, taken from satellite (International Satellite Cloud Climatology Project, ISCCP-D2), Global Reanalysis projects (National Centers for Environmental Prediction - National Center for Atmospheric Research, NCEP/NCAR), and other global databases. The spectral aerosol optical properties (aerosol optical depth, AOD, asymmetry parameter, $g_{\text {aer }}$ and single scattering albedo, $\omega_{\text {aer }}$ ), are taken from the MODerate resolution Imaging Spectroradiometer (MODIS) of NASA (National Aeronautics and Space Administration) and they are supplemented by the Global Aerosol Data Set (GADS). The model SSR fluxes have been successfully validated against measurements from 80 surface stations of the Global Energy Balance Archive (GEBA) covering the period 20002007.

A planetary cooling is found above the Mediterranean on an annual basis (regional mean $\mathrm{DRE}_{\mathrm{TOA}}=-2.4 \mathrm{~W} \mathrm{~m}^{-2}$ ).
\end{abstract}

Although a planetary cooling is found over most of the region, of up to $-7 \mathrm{~W} \mathrm{~m}^{-2}$, large positive $\mathrm{DRE}_{\mathrm{TOA}}$ values (up to $+25 \mathrm{~W} \mathrm{~m}^{-2}$ ) are found over North Africa, indicating a strong planetary warming, and a weaker warming over the Alps $\left(+0.5 \mathrm{~W} \mathrm{~m}^{-2}\right)$. Aerosols are found to increase the absorption of solar radiation in the atmospheric column over the region $\left(\mathrm{DRE}_{\mathrm{atm}}=+11.1 \mathrm{~W} \mathrm{~m}^{-2}\right)$ and to decrease SSR $\left(\mathrm{DRE}_{\text {surf }}=-16.5 \mathrm{~W} \mathrm{~m}^{-2}\right.$ and $\left.\mathrm{DRE}_{\text {netsurf }}-13.5 \mathrm{~W} \mathrm{~m}^{-2}\right)$ inducing thus significant atmospheric warming and surface radiative cooling. The calculated seasonal and monthly DREs are even larger, reaching $-25.4 \mathrm{~W} \mathrm{~m}^{-2}$ (for $\mathrm{DRE}_{\text {surf }}$ ). Within the range of observed natural or anthropogenic variability of aerosol optical properties, AOD seems to be the main responsible parameter for modifications of regional aerosol radiative effects, which are found to be quasi-linearly dependent on AOD, $\omega_{\text {aer }}$ and $g_{\text {aer }}$.

\section{Introduction}

Atmospheric aerosols influence the Earth's climate by modifying its energy balance through the direct, indirect and semidirect effects. However, the uncertainty of aerosol effects on the Earth's radiation budget greatly exceeds that of any other climate forcing agent (Kaufman et al., 2002; Forster, 2007; Vardavas and Taylor, 2011). This is due to the fact that the aerosol physical, chemical and optical properties are highly 
variable in space and time, because of the short atmospheric lifetime of aerosols and of their inhomogeneous emissions (Quinn and Bates, 2005; Forster, 2007). Improved assessments of aerosol radiative effects are essential for reducing the uncertainty of future climate changes (IPCC, 2007) and have to be performed not only on global but also on regional scales. Such assessments are also important in the context of changes in solar radiation at the Earth's surface, commonly known as global dimming and brightening, which are of primary importance for the Earth's climate and have received much attention lately (see Wild, 2009).

The role of aerosols is even more crucial over climatically sensitive regions like the Mediterranean basin, which is a crossroad where aerosols from different sources are mixed. These aerosols include fine anthropogenic aerosols from Europe, desert dust from North Africa and the Middle East, and maritime aerosols from the Mediterranean Sea and the Atlantic Ocean (e.g. Lelieveld et al., 2002; Sciare et al., 2003; Pace et al., 2006; Lyamani et al., 2006; Gerasopoulos et al., 2006; Kalivitis et al., 2007). The role of aerosols is enhanced because of the large amount of solar radiation reaching the Mediterranean basin, especially during summer cloud-free conditions. The regional annual mean value of aerosol optical depth at $550 \mathrm{~nm}\left(\mathrm{AOD}_{550}\right)$, a good measure of atmospheric aerosol loading, has been recently determined at 0.22 (Papadimas et al., 2008) a value 1.3 times larger than the corresponding global average of 0.17 (Remer et al., 2008). Nevertheless, a typical feature in the region is the strong spatial and temporal variability of the aerosol, modulated by the local, synoptic and large-scale circulation (di Sarra et al., 2001; Kallos et al., 2007).

The aerosol radiative effects over the Mediterranean region have been studied by many researchers in the last decade (e.g. Formenti et al., 2002; Markowicz et al., 2002; Meloni et al., 2003; Haywood et al., 2003; Balis et al., 2004; Roger et al., 2006; di Sarra et al., 2008; Saha et al., 2008, Bergamo et al., 2008, Santos et al., 2008; Di Biagio et al., 2009, 2010; Kazadzis et al., 2009; Santese et al., 2010). Nevertheless, most of these studies are temporally and spatially limited, since they are based on station measurements at specific sites or experimental campaigns that took place in parts of the Mediterranean region (e.g. MINOS experiment, Sahara Dust Experiment, SHADE). Moreover, most of the earlier published DRE computations refer either to anthropogenic or to natural aerosols, separately. Understanding of the aerosol effects on the atmospheric dynamics and climate of the region requires investigation of the spatial variation of the aerosol effects on the regional radiation budget, accounting for both natural and anthropogenic aerosols that co-exist and interact in the region (e.g. Hatzianastassiou et al., 2009). To this aim, it is crucial to perform computations of aerosol radiative effects for the entire Mediterranean basin.

The present modelling study attempts to compute, for the first time to our knowledge, the direct effect of aerosols (natural plus anthropogenic) on the radiative energy bud- get of the broader Mediterranean basin $\left(29.5^{\circ} \mathrm{N}-46.5^{\circ} \mathrm{N}\right.$ and $10.5^{\circ} \mathrm{W}-38.5^{\circ} \mathrm{E}$ ) for the 7-yr period from March 2000 to February 2007 using contemporary satellite and reanalyses data. This is achieved by using the available observational data as input to a detailed spectral radiative transfer model (RTM). The RTM uses as input spectral aerosol optical properties (AOD, asymmetry parameter, $g_{\text {aer }}$, and single scattering albedo, $\left.\omega_{\text {aer }}\right)$ taken mainly from the MODerate resolution Imaging Spectroradiometer (MODIS, King et al., 2003; Remer et al., 2005) of NASA (National Aeronautics and Space Administration) and supplemented by the Global Aerosol Data Set (GADS, Koepke et al., 1997). The use of spectral aerosol optical properties along with a detailed spectral RTM in the present study, ensures the calculation of quality aerosol DRE values since, as it has been shown in previous studies (e.g. Hatzianastassiou et al., 2004b, 2007b; di Sarra et al., 2008), aerosol radiative effects are quite sensitive to the spectral dependence of aerosol optical properties. The additional surface and atmospheric parameters that are required as input such as clouds, water vapour, surface albedo and ozone, are taken from comprehensive global climatological databases (mainly the International Satellite Cloud Climatology Project, ISCCP) and global reanalyses (NCEP/NCAR). The model computes the aerosol DRE on the various components of the regional SW radiation budget, namely at the reflected solar radiation at TOA (at $50 \mathrm{mb}$, i.e. the top of troposphere), within the atmosphere (on the absorbed solar radiation), and at the surface (on the incoming and absorbed solar radiation) at a spatial resolution of $2.5^{\circ} \times 2.5^{\circ}$ latitudelongitude and on a monthly mean basis. The computations are performed under real all-sky conditions, but also under clear-skies. Apart from the geographical patterns and seasonal variability of DREs, the aerosol-induced inter-annual changes of solar radiation in the Mediterranean basin over the study period are also estimated by applying linear regression fits to the 7-yr time series of DRE components.

The methodology and the description of RTM and its input data are given in Sect. 2. The model results and the validation of SW fluxes and aerosol DREs are discussed in Sect. 3, whereas the results of the model sensitivity tests are presented in Sect. 4. Conclusions are summarized in Sect. 5.

\section{Model and input data}

\subsection{The spectral radiative transfer model}

The spectral radiative transfer model (Vardavas and Carver, 1984; Hatzianastassiou et al., 2004a; 2007a, b; Vardavas and Taylor, 2011) computes solar radiative fluxes at 118 wavelengths in the range $0.2-1.0 \mu \mathrm{m}$ and 10 spectral intervals in the range $1.0-10 \mu \mathrm{m}$. The computations are performed for each $2.5^{\circ}$ latitude $\times 2.5^{\circ}$ longitude cell of the region under both clear- and cloudy-sky conditions, considering ozone absorption, Rayleigh scattering, and absorption by water 
vapour, carbon dioxide and methane. Scattering and absorption by clouds (low, middle and high) and aerosols, and reflection from the Earth's surface are also taken into account. A complete description and detailed model considerations can be found in previous publications (Hatzianastassiou and Vardavas, 1999; 2001; Hatzianastassiou et al., 2004a, b, c, 2005; Hatzianastassiou et al., 2007a). The aerosol DRE is computed as the difference between model computed fluxes with $\left(F_{\mathrm{i}}\right)$ and without $\left(F_{\mathrm{i}, \text { no-aerosol }}\right)$ the presence of aerosols:

$$
\begin{aligned}
& \mathrm{DRE}_{\text {atm }}=F_{\mathrm{atm}}-F_{\text {atm,no-aerosol }} \\
& \mathrm{DRE}_{\text {surf }}=F_{\text {surf }}-F_{\text {surf,no-aerosol }} \\
& \mathrm{DRE}_{\mathrm{TOA}}=F_{\mathrm{TOA}, \text { no-aerosol }}-F_{\mathrm{TOA}}
\end{aligned}
$$

The DRE components quantify the effect of aerosols on solar

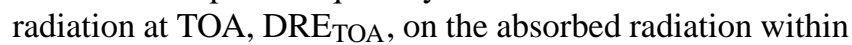
the atmosphere, $\mathrm{DRE}_{\mathrm{atm}}$, and on the downward, $\mathrm{DRE}_{\text {surf }}$, and net downward or absorbed radiation DRE $E_{\text {netsurf }}$ at the Earth's surface.

Apart from DRE, the aerosol radiative efficiency $\left(\mathrm{E}_{\mathrm{AOD}, \mathrm{i}}\right)$ which is used to isolate the AOD dependence of DRE, is also investigated in this study. $\mathrm{E}_{\mathrm{AOD}, \mathrm{i}}$ (Eq. 4) is the aerosol perturbation of solar radiation, at TOA, in the atmosphere and at the surface ( $E_{A O D, T O A}, E_{A O D, a t m}, E_{A O D, n e t s u r f}$, respectively) per unit of optical depth $\left(\mathrm{AOD}_{550}^{-1}\right)$ and is expressed in $\mathrm{W} \mathrm{m}^{-2}$

$E_{\mathrm{AOD}, \mathrm{i}}=\mathrm{DRE}_{\mathrm{i}} / \mathrm{AOD}_{550}$

(AOD is usually given at the 0.5 or $0.55 \mu \mathrm{m}$ visible wavelengths). Provided that $\mathrm{E}_{\mathrm{AOD}, i}$ is known, for a given AOD, the product of $\mathrm{AOD}$ and $\mathrm{E}_{\mathrm{AOD}, i}$ provides an estimate of aerosol climatic effects (Anderson et al., 2005; Christopher and Jones, 2008). $\mathrm{E}_{\mathrm{AOD}, i}$ is also useful since it removes the significant geographical dependence of AOD, and thus can be used to evaluate the performance of models.

As another useful measure of the impact of aerosols on solar radiation we define the so-called aerosol radiation (budget) efficiency (ARBE). This quantifies the ability of aerosols to modify the solar radiation fluxes, and can be defined as

$\mathrm{ARBE}_{i}=\mathrm{DRE}_{\mathrm{i}} / F_{\mathrm{i}, \text { no-aerosol }}$

which, based on Eqs. (1), (2), and (3), is equivalent to

$\mathrm{ARBE}_{\mathrm{i}}=F_{\mathrm{i}} / F_{\mathrm{i}, \text { no-aerosol }}$

for index -i corresponding to "atm" and "surf", and

$\mathrm{ARBE}_{\mathrm{i}}=1-F_{\mathrm{i}} / F_{\mathrm{i}, \text { no-aerosol }}$

for -i corresponding to "TOA".

\subsection{Aerosol optical properties}

Spectral aerosol optical properties (AOD, $\omega_{\text {aer }}$, and $g_{\text {aer }}$ ) are required for model computations at all wavelengths and spectral bands from 0.25 to $10 \mu \mathrm{m}$. In this study, we use mean monthly AOD and $g_{\text {aer }}$ MODIS Terra (Collection 5 and 5.1) Level-3 data (http://modaps.nascom.nasa.gov/), for the available wavelengths, i.e. $0.47,0.55,0.66,0.87,1.24,1.64$, and 2.13 micrometers, supplemented by GADS data (Koepke et al., 1997) for the remaining wavelengths. The MODIS data are available over land and ocean and provide complete spatial and temporal coverage over the broader Mediterranean basin. The pre-launch uncertainty of the MODIS AOD is $\pm 0.05 \pm 0.2 \times$ AOD over land (Chu et al., 2002), and $\pm 0.03 \pm 0.05 \times$ AOD over ocean (Remer et al., 2002). Over the Mediterranean basin, according to an extensive validation of MODIS Collection 005 against AERONET (Papadimas et al., 2009), the MODIS AOD data are slightly (by $1 \%)$ underestimated. The $\omega_{\text {aer }}$ data are taken from GADS because MODIS $\omega_{\text {aer }}$ data (Deep Blue) are not available for the study period, they are limited to over land and, in addition, they do not entirely cover the study region, especially its northern part (southern European coastal areas). Furthermore, MODIS Deep Blue $\omega_{\text {aer }}$ data have not been adequately evaluated. The original GADS $\omega_{\text {aer }}$ data, are re-computed for actual relative humidity values for the aerosol layer as explained by Hatzianastassiou et al. (2004a) and extensively discussed by Hatzianastassiou et al. (2007a). More specifically, global distributions of GADS aerosol properties are given as climatologically averaged values both for the periods December through February (Northern Hemisphere winter) and June through August (Northern Hemisphere summer) on a $5^{\circ} \times 5^{\circ}$ latitude-longitude resolution. To match the spatial resolution of the climatological parameters, especially that of relative humidity to which the aerosol properties are sensitive, the original GADS aerosol optical properties were downscaled to $2.5^{\circ} \times 2.5^{\circ}$ latitude-longitude resolution, as explained in Hatzianastassiou et al. (2004a). The aerosol single scattering albedo originally given in GADS for winter and summer, for different fixed relative humidity values, was linearly interpolated for all months by taking the mean winter and summer values to correspond to January and July, respectively. The monthly values were then re-computed for actual monthly relative humidity values for the aerosol layer in order to compute more realistically the aerosol DREs for the study period 2000-2007. It should be acknowledged, however, that this treatment of $\omega_{\text {aer }}$ by GADS is not entirely realistic, and does not capture specific aerosol events, like that associated with the summer 2003 heat wave that induced extensive biomass burning (Hodzic et al., 2007). We then assessed our re-computed, and finally used, GADSbased $\omega_{\text {aer }}$ data through comparisons against the available $\omega_{\text {aer }}$ data from MODIS deep-blue (Hsu et al., 2004). It was found that at $550 \mathrm{~nm}$ they are underestimated with respect to MODIS $\omega_{\text {aer }}$ data by $0-10 \%$, with an overall, i.e. regional mean, underestimation of $8 \%$. We have performed a similar inter-comparison for the globe, which revealed an overall underestimation by GADS $\omega_{\text {aer }}$ equal to $3 \%$. The consequences of the uncertainty of GADS-based model input $\omega_{\text {aer }}$ data on aerosol DREs are discussed in Sect. 5. 


\subsection{Surface and atmospheric data}

The monthly mean water vapour and temperature data were taken from the NCEP/NCAR Global Reanalysis Project (Kalnay et al., 1996; Kistler et al., 2001). Monthly mean cloud properties (cloud amount, cloud-top pressure, cloudtop temperature, liquid water path, cloud albedo, and optical depth for total, as well as low-, mid-, and high-level clouds) on $2.5^{\circ} \times 2.5^{\circ}$ grid cell resolution were taken from the latest D2 stage data of ISCCP (Rossow et al., 1996; Rossow and Schiffer, 1999). The treatment of surface reflection is explained in detail by Vardavas and Koutoulaki (1995) and Hatzianastassiou et al. (2004a, 2005, 2007a). The mean monthly 2.5-degree latitude-longitude grid cell data of the total $\mathrm{O}_{3}$ column abundance (in Dobson Units) were taken from TOVS, archived in the ISCCP-D2 package. For $\mathrm{CO}_{2}$ a fixed total atmospheric amount is taken, equal to $0.54 \mathrm{~g} \mathrm{~cm}^{-2}$, corresponding to 345 parts per million by volume (ppmv). Note that increasing carbon dioxide concentration to recently recorded levels of $380 \mathrm{ppmv}$ in the Mediterranean and the globe had a negligible effect on the model computed aerosol DRE values (smaller than $0.02 \%$ ). The treatment of solar absorption by atmospheric molecules is explained by Hatzianastassiou et al. (2004a, 2007a), whereas the Rayleigh scattering, due to air molecules, is considered in the model in the same way as in Vardavas and Carver (1984) and Hatzianastassiou et al. (2004a).

\section{Results}

\subsection{Model validation}

The aerosol direct effect on surface solar radiation, i.e. DRE $_{\text {surf }}$, is very important because SSR plays a key role for many processes of the Earth-atmosphere system, for example surface heating or evaporation. Before the presentation of model computed DRE results, it is important to assess their reliability. Unfortunately, direct validation of the model computation of $\mathrm{DRE}_{\text {surf }}$ is not feasible owing to the absence of measurements of surface solar radiation fluxes in the absence of aerosol particles, $F_{\text {surf,no-aerosol }}$ (Eq. 2). Therefore, the quality of model computations of $\mathrm{DRE}_{\text {surf }}$ can be assessed only by the validation of the computations of the other component, i.e. that of surface solar radiation in the presence of aerosols, $F_{\text {surf }}$ (Eq. 2).

The quality of model DRE $\mathrm{surf}_{\text {in }}$ in this study was assessed by validating the monthly mean $2.5^{\circ} \times 2.5^{\circ}$ downward surface solar radiation (SSR) fluxes over the broader Mediterranean basin, through comparisons with corresponding high-quality surface measurements, over the study period (2000-2007). The surface SSR measurements were taken from the Global Energy Balance Archive (GEBA, Gilgen and Ohmura, 1999). GEBA database, redesigned and updated in 1994 and 1995, contains quality controlled monthly mean energy fluxes at the Earth's surface from sites all over the world. The GEBA data are widely used for validation of model and satellite remote sensing retrieval algorithms because of the large number of stations and the long observational period (Wild et al., 1995; Kiehl and Trenberth, 1997; Hatzianastassiou et al., 2005).

GEBA and modelled SSR fluxes have been compared for those pixels including GEBA stations that are located within the study region and operated within the period 2000-2007. A total of 80 GEBA stations satisfied this criterion and were used in this study for the model evaluation. These stations ensure a satisfactory spatial coverage of our study region being homogeneously distributed. Figure S1a in the Supplement presents the overall comparison between model and GEBA monthly SSR fluxes. There is a large number of matched data pairs $(N=4843)$, enabling thus good statistics. The scatterplot comparison reveals a good agreement between model and GEBA SSR, with a bias equal to $-8.1 \mathrm{~W} \mathrm{~m}^{-2}$ (or $-5.3 \%$ ), indicating a general model underestimation of SSR, with a relatively small scatter $\left(\mathrm{SD}=19.08 \mathrm{~W} \mathrm{~m}^{-2}\right)$. The correlation coefficient between model and GEBA fluxes is satisfactory and equal to 0.95 .

Apart from the overall comparison, the ability of model SSR to reproduce the inter-annual variability and tendencies of SSR based on surface measurements, has been also tested on the basis of complete time-series. For this purpose, in order to ensure reliable estimates of SSR tendencies, those GEBA stations providing at least $80 \%$ of the total number of monthly data over our study period (2000-2007) have been selected. Only four (4) GEBA stations met this criterion. In Table S1 of the Supplement the model computed changes of SSR, $\Delta$ (SSR), over the period 2000-2007 are compared with the corresponding changes from GEBA measurements, for each station. The computed correlation coefficients and the relative differences between the two sets of SSR fluxes are also given. Figure S1b in the Supplement shows the interannual variability and tendencies of the model and GEBA SSR fluxes, based on applied linear regression fits to the two time-series. The comparisons reveal that our model is able to adequately reproduce the inter-annual variation and the tendencies of SSR.

The different spatial resolution of model radiative fluxes, computed here at $2.5^{\circ} \times 2.5^{\circ}$ latitude-longitude cells, and surface measurements, referring to specific locations, could be a problem, given the significant sub-grid variability of surface (for example surface albedo) and atmospheric (e.g. aerosol, cloud) conditions. In order to assess this uncertainty it is useful to bring closer the spatial scales of model and surface fluxes. This can be done more efficiently by downscaling the model fluxes than upscaling the surface measurements keeping in mind that, given the nature and techniques of satellite observations and of the associated aerosol and other parameters (e.g. clouds) retrievals, on which our model computations are based and dependent, an ideal match between the model and surface spatial scales is not possible. Given the 
Table 1. Regional mean values of aerosol direct radiative effect (DRE, in $\mathrm{W} \mathrm{m}^{-2}$ ) over the broader Mediterranean basin under all-sky

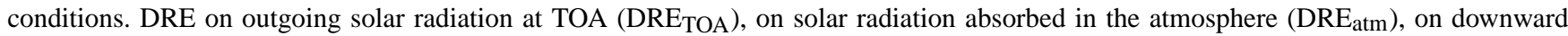

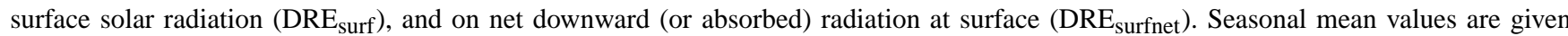
for winter (November-December-January, DJF), spring (March-April-May, MAM), summer (June-July-August, JJA), autumn (SeptemberOctober-November, SON) and for the entire period (2000-2007). The values in parentheses indicate the corresponding quantities under clear-sky conditions.

\begin{tabular}{|c|c|c|c|c|}
\hline & \multirow[t]{2}{*}{ TOA (DRE $\left.{ }_{\mathrm{TOA}}\right)$} & \multirow[t]{2}{*}{ Atmosphere (DRE $\left.\mathrm{Dtm}_{\mathrm{atm}}\right)$} & \multicolumn{2}{|c|}{ Surface } \\
\hline & & & $\mathrm{DRE}_{\text {surf }}$ & DRE $_{\text {netsurf }}$ \\
\hline Year & $-2.4 \pm 0.3(-4.5 \pm 0.4)$ & $11.1 \pm 0.7(14.3 \pm 0.7)$ & $-16.5 \pm 1.0(-22.9 \pm 1.2)$ & $-13.5 \pm 0.9(-18.8 \pm 1.0)$ \\
\hline DJF & $-0.9 \pm 0.1(-2.6 \pm 0.1)$ & $4.5 \pm 2.2(7.4 \pm 3.3)$ & $-7.0 \pm 2.9(-13.0 \pm 4.6)$ & $-5.4 \pm 2.1(-10.0 \pm 3.4)$ \\
\hline MAM & $-2.4 \pm 0.7(-5.2 \pm 0.9)$ & $14.7 \pm 2.7(19.2 \pm 2.9)$ & $-20.9 \pm 3.9(-29.7 \pm 4.0)$ & $-17.1 \pm 3.2(-24.4 \pm 3.6)$ \\
\hline JJA & $-4.3 \pm 0.5(-6.3 \pm 0.4)$ & $17.5 \pm 0.7(20.1 \pm 1.1)$ & $-26.2 \pm 1.0(-31.7 \pm 1.3)$ & $-21.8 \pm 0.9(-26.5 \pm 1.1)$ \\
\hline SON & $-1.9 \pm 0.5(-3.8 \pm 0.5)$ & $7.7 \pm 4.0(10.4 \pm 4.0)$ & $-11.8 \pm 5.7(-17.3 \pm 5.6)$ & $-9.6 \pm 4.6(-14.2 \pm 4.4)$ \\
\hline
\end{tabular}

characteristics of MODIS satellites, instrumentation, and inversion techniques, the best possible spatial resolution of the present model input data and radiative fluxes is $10 \times 10 \mathrm{~km}^{2}$, that is much finer than the $280 \times 280 \mathrm{~km}^{2}\left(2.5^{\circ} \times 2.5^{\circ}\right)$ used here. Extensive comparisons between our model SSR fluxes computed at $10 \times 10 \mathrm{~km}^{2}$ and surface station measurements (see Benas et al., 2011) have shown that, in that case, model fluxes agree with surface measurements within $4.5-9.2 \%$, comparable to present study (3-11\%), with a negative bias as also in our study (Fig. S1 in the Supplement). The similarity between the results of validation of model SSR, computed either at $10 \times 10 \mathrm{~km}^{2}$ or $280 \times 280 \mathrm{~km}^{2}$, against surface reference measurements adds relevance to the results presented here.

\subsection{Regional mean patterns}

\subsubsection{DRE TOA}

The seven-year (2000-2007) average geographical distribution of aerosol direct radiative effect on the outgoing shortwave radiation at TOA, for all-sky conditions, over the broader Mediterranean basin is given in Fig. 1i-a, indicating mostly negative and more sparse positive $\mathrm{DRE}_{\mathrm{TOA}}$ values. The model 7-yr regional mean aerosol DRETOA (see also Table 1) is equal to $-2.4 \pm 0.3 \mathrm{~W} \mathrm{~m}^{-2}$ (standard deviation corresponds to inter-annual variability), indicating that on an annual basis, aerosols induce a significant "planetary" cooling over the broader Mediterranean basin, equivalent to an increase in the mean regional planetary albedo by $2.3 \%$. Our analysis shows, however, that there is spatial variability in $\mathrm{DRE}_{\mathrm{TOA}}$ within the study region, for example between the eastern, central and western Mediterranean basins (DRE $\mathrm{DOA}_{\mathrm{TO}}$ values equal to $-2.5,-3.4$, and $-1.2 \mathrm{~W} \mathrm{~m}^{-2}$, respectively, see Tables S2, S3, S4 of Supplement). Local DRE $\mathrm{TOA}_{\mathrm{TO}}$ values range mostly between -7 and $0 \mathrm{~W} \mathrm{~m}^{-2}$ (planetary cooling) but reach positive values (planetary warming) up to $28 \mathrm{~W} \mathrm{~m}^{-2}$. The planetary warming arises from the significant absorption of solar radiation either by natural mineral dust aerosols over the bright reflecting surfaces of Sahara desert, or by pollution anthropogenic aerosols over the iceor snow-covered mountain slopes of the Alps. This effect is enhanced through multiple reflections between the absorbing aerosol layers and the highly reflecting surfaces underneath (e.g. Charlson et al., 1992; Haywood and Shine; 1997; Myhre et al., 1998; Hatzianastassiou et al., 2004a, b, 2007a).

The localized weak aerosol planetary warming over the Alps is interesting and similar, though smaller in magnitude (due to smaller AOD and surface albedo values), to the corresponding warming effect of Arctic haze that has been documented in the literature (Rinke et al., 2004; Treffeisen et al., 2005; Law and Stohl, 2007). The very large positive DRE $_{\text {TOA }}$ values over the Sahara desert (up to $28 \mathrm{~W} \mathrm{~m}^{-2}$ ) are due to high aerosol loading (AOD) and to low $\omega_{\text {aer }}$ values there (down to 0.88 at $550 \mathrm{~nm}$ according to our data). Note that computed DRE $\mathrm{TOA}_{\mathrm{T}}$ over the Sahara desert are very sensitive to the adopted $\omega_{\text {aer }}$ values since a decrease by up to $10.6 \mathrm{~W} \mathrm{~m}^{-2}$ is calculated when $\omega_{\text {aer }}$ at $550 \mathrm{~nm}$ is increased by $10 \%$. A similar to the Sahara desert aerosol effect (planetary warming, $\mathrm{DRE}_{\mathrm{TOA}}>0$ ) is also observed over the Middle East. On the other hand, the largest negative values, up to $-7 \mathrm{~W} \mathrm{~m}^{-2}$, are computed over the Mediterranean Sea, and are due to high aerosol loads (up to 0.4, see Papadimas et $\mathrm{al}, 2008)$ and to low sea surface albedo (0.08 to 0.1$)$. In order to further clarify the role of surface albedo on aerosol $\mathrm{DRE}_{\mathrm{TOA}}$, but also $\mathrm{DRE}_{\mathrm{atm}}$ and $\mathrm{DRE}_{\text {surf }}$ (discussed in the following sub-sections), we have distinguished and classified the study region into the three main surface types, land, ocean and desert. Subsequently, we grouped and computed DRE values for each one of the three surface types (Table 2). On an annual (7-yr) and regional mean basis, over deserts, a positive sign in the desert DRE $\mathrm{TOA}_{\mathrm{TO}}$ value $\left(4.1 \mathrm{~W} \mathrm{~m}^{-2}\right)$ is calculated, implying a planetary warming there opposite to planetary cooling over land and ocean. The planetary cooling has, however, smaller magnitude over land than oceans $(-0.4$ against $-5.4 \mathrm{~W} \mathrm{~m}^{-2}$, respectively) because of the larger surface albedo in the former case. 


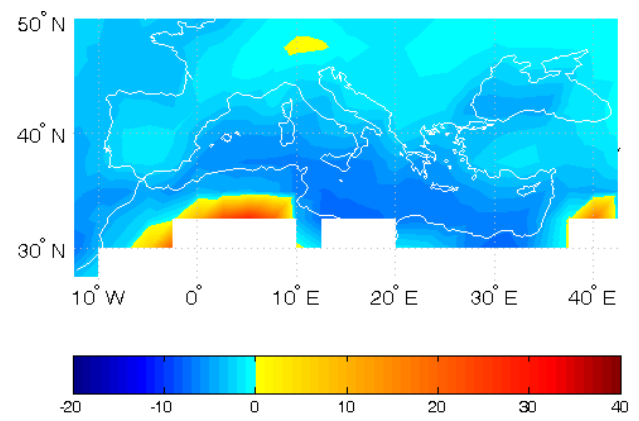

(i-a)

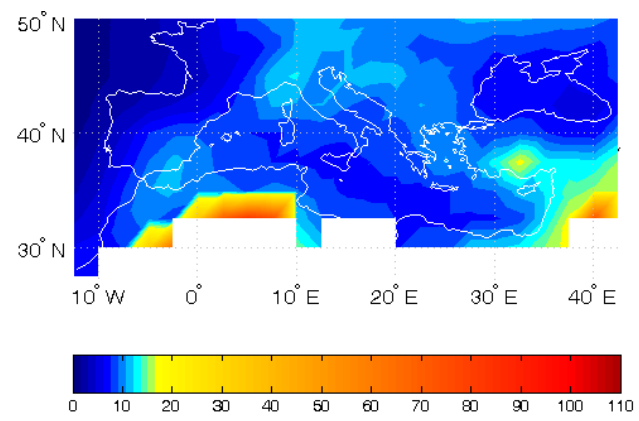

(ii-a)

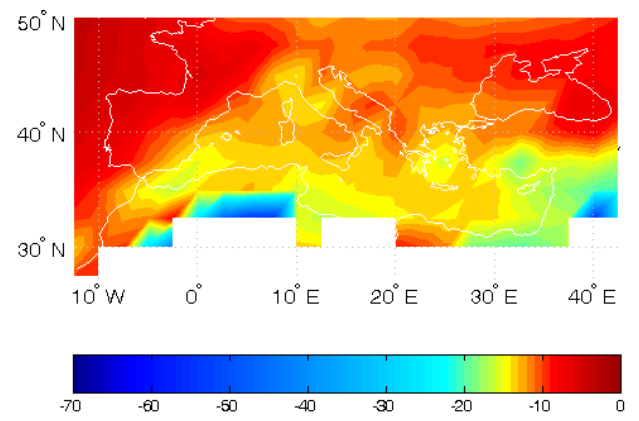

(iii-a)

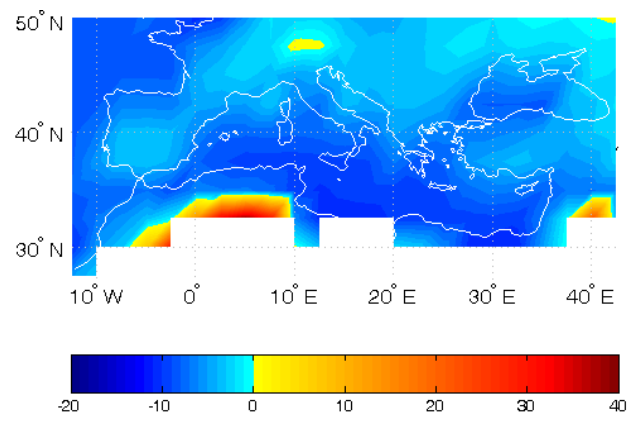

(i-b)

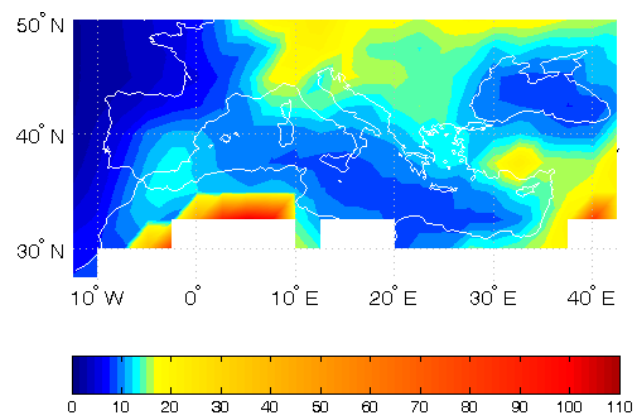

(ii-b)

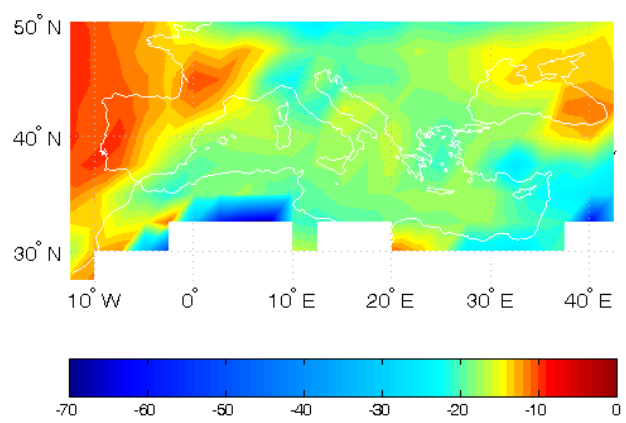

(iii-b)

Fig. 1. Seven-year (2000-2007) average geographical distribution of aerosol direct radiative effect: (i) on the outgoing shortwave radiation at the top of the atmosphere ( $\mathrm{DRE}_{\mathrm{TOA}}$, in $\mathrm{W} \mathrm{m}^{-2}$ ), (ii) on the atmospheric absorption of shortwave radiation $\left(\mathrm{DRE}_{\mathrm{atm}}\right.$, in $\left._{\mathrm{W} \mathrm{m}}{ }^{-2}\right)$, and (iii) on the absorbed solar radiation at the Earth's surface $\left(\mathrm{DRE}_{\text {netsurf }}\right.$, in $\mathrm{W} \mathrm{m}^{-2}$ ) over the broader Mediterranean basin. The results are given under: (a) all-sky conditions and (b) clear-sky conditions.

Table 2. Regional annual mean values (2000-2007) of aerosol direct radiative effect $\left(\mathrm{DRE}_{\mathrm{TOA}}, \mathrm{DRE}_{\mathrm{atm}}, \mathrm{DRE}_{\text {surf }}\right.$, and $\mathrm{DRE}_{\text {surfnet }}$, in $\mathrm{W} \mathrm{m}^{-2}$ ) for land, ocean and desert areas of the broader Mediterranean basin under all-sky conditions.

\begin{tabular}{lrrrr}
\hline Year & DRE $_{\mathrm{TOA}}$ & $\mathrm{DRE}_{\text {atm }}$ & DRE $_{\text {surf }}$ & DRE $_{\text {netsurf }}$ \\
\hline Land & -0.4 & 13.5 & -18.2 & -13.9 \\
Ocean & -5.4 & 6.0 & -12.2 & -11.4 \\
Desert & 4.1 & 25.8 & -31.6 & -21.7 \\
\hline
\end{tabular}

The magnitude of $\mathrm{DRE}_{\mathrm{TOA}}$ values is largest in the southern part of the region because of cloud-free conditions and high solar radiation. Values there are either negative, over the Mediterranean Sea, or positive, over northern Africa and Middle East, due to the relatively high surface albedo over deserts and the low albedo over sea water. The highly populated and industrialized urban areas of central and west Europe are found to have relatively smaller $\mathrm{DRE}_{\mathrm{TOA}}$ values (up to $-1.5 \mathrm{~W} \mathrm{~m}^{-2}$ ) due to the absence of the synergistic effects of the above factors. To investigate the role of cloudiness, $\mathrm{DRE}_{\mathrm{TOA}}$ has been computed under clear-sky conditions (see 
Fig. 1i-b). The results show that the aerosol effect is larger than under all-sky conditions, with a 7-yr regional mean DRE $_{\text {TOA }}$ equal to $-4.5 \pm 0.4 \mathrm{~W} \mathrm{~m}^{-2}$ (Table 1), i.e. by $87.5 \%$ larger than all-sky, and with local $\mathrm{DRE}_{\mathrm{TOA}}$ values ranging between -11 and $38 \mathrm{~W} \mathrm{~m}^{-2}$.

On a seasonal basis (Fig. S2 in the Supplement) the largest negative $\mathrm{DRE}_{\mathrm{TOA}}$ values over the sea are found in spring and summer, and subsequently for autumn, for the western, central and eastern Mediterranean. Note that while $\mathrm{DRE}_{\mathrm{TOA}}$ is dominated by a very strong latitudinal gradient, no clear longitudinal gradient is here calculated, opposite to earlier studies (e.g. Moulin et al., 1998; Israelevich et al., 2002; Meloni et al., 2007; Papadimas et al., 2008; Di Iorio et al., 2009) that report differences between western, central and eastern Mediterranean, in AOD. The seasonal regional mean aerosol $\mathrm{DRE}_{\mathrm{TOA}}$ values, and the corresponding standard deviations, are equal to $-0.9 \pm 0.1,-2.4 \pm 0.7$, $-4.3 \pm 0.5,-1.9 \pm 0.5 \mathrm{~W} \mathrm{~m}^{-2}$, for winter (December to February), spring (March to May), summer (June to August), and autumn (September to November), respectively (see also Table 1), showing a clear maximum in summer. The corresponding seasonal regional mean $\mathrm{AOD}_{550}$ values are $0.13 \pm 0.02,0.22 \pm 0.03,0.24 \pm 0.03,0.16 \pm 0.03 \mathrm{~W} \mathrm{~m}^{-2}$, also with a summer maximum, but not so distinct as that of $\mathrm{DRE}_{\mathrm{TOA}}$ and comparable to the spring $\mathrm{AOD}_{550}$ maximum. Note that the summer/winter ratio of $\mathrm{DRE}_{\mathrm{TOA}}$ is equal to 4.8 , which is larger than the corresponding summer/winter ratio of $\mathrm{AOD}_{550}$ (1.8). The summer/spring ratios of $\mathrm{DRE}_{\mathrm{TOA}}$ and $\mathrm{AOD}_{550}$ are equal to 1.8 and 1.1, respectively, i.e. again higher for $\mathrm{DRE}_{\mathrm{TOA}}$ than $\mathrm{AOD}_{550}$. These results highlight the important role of available solar radiation for the magnitude of DRE $E_{\mathrm{TOA}}$, apart from that of aerosol optical properties. The summertime primary maxima of $\mathrm{DRE}_{\mathrm{TOA}}$ reflect the high solar radiation and the impact of pollution aerosols that are abundant in the absence of rain during summer. Furthermore, the secondary maxima in spring is associated with the influence of desert dust transport, from North Africa and Middle East, to the Mediterranean during spring (Barnaba and Gobbi, 2004; Papadimas et al., 2008).

Our model DRE $\mathrm{TOA}_{\mathrm{T}}$ values were compared with corresponding existing independent estimates in the Mediterranean, and the results are encouraging. Thus, for example, di Biagio et al. (2010) computed daily values of DRETOA at the Lampedusa island, for equinox and summer solstice, equal to -4.5 and $-5 \mathrm{~W} \mathrm{~m}^{-2}$, respectively, compared to our model values of -10.6 and $-13.6 \mathrm{~W} \mathrm{~m}^{-2}$. Vrekoussis et al. (2005) estimated seasonal $\mathrm{DRE}_{\mathrm{TOA}}$ values at Crete island ranging from $-2.3 \mathrm{~W} \mathrm{~m}^{-2}$ for winter to $-12.6 \mathrm{~W} \mathrm{~m}^{-2}$ for summer. Our corresponding $\mathrm{DRE}_{\mathrm{TOA}}$ values are equal to -2.4 and $-9.5 \mathrm{~W} \mathrm{~m}^{-2}$. Again for Crete island, Markowicz et al. (2002) reported a DRE $\mathrm{TOA}$ value equal to $-8.3 \mathrm{~W} \mathrm{~m}^{-2}$ which perfectly matches with our value of $-8.4 \mathrm{~W} \mathrm{~m}^{-2}$. The comparison is encouraging taking into account that our model results are for $2.5^{\circ} \times 2.5^{\circ}$ latitude-longitude geographical cells, whilst the others' independent estimates are given for specific sites falling within our cell, in each case.

\subsubsection{DRE $_{a t m}$}

Annually, the regional average $\mathrm{DRE}_{\mathrm{atm}}$ is equal to $11.1 \pm 0.7 \mathrm{~W} \mathrm{~m}^{-2}$ (Table 1) with values of $13.5,6.0$ and $25.8 \mathrm{~W} \mathrm{~m}^{-2}$ over land, ocean and desert areas, respectively (Table 2). According to our model computations, the regional $\mathrm{DRE}_{\mathrm{atm}}\left(11.1 \mathrm{~W} \mathrm{~m}^{-2}\right)$ is about triple that of the global mean $\mathrm{DRE}_{\mathrm{atm}}$ value of $3.9 \mathrm{~W} \mathrm{~m}^{-2}$, demonstrating thus that Mediterranean has one of the most significant absorbing aerosol loadings in the world (e.g., Lelieveld et al., 2002). DRE $_{\text {atm }}$ values as high as $12 \mathrm{~W} \mathrm{~m}^{-2}$ are also computed for central Europe, associated with absorbing pollution aerosols, while over the Mediterranean Sea the values vary between 5 and $10 \mathrm{~W} \mathrm{~m}^{-2}$. However, they can be much larger, up to a several tens of $\mathrm{W} \mathrm{m}^{-2}$, over specific areas with absorbing dust aerosols (e.g.Markowicz et al., 2002), like the Anatolia peninsula, Middle-East and northern Africa. The DRE atm values are higher over the Mediterranean Sea than the Atlantic Ocean by factors of 2-3, because the Mediterranean Sea experiences higher aerosol background levels than the open Atlantic Ocean, due to long range and regional transport from upwind continental areas (e.g. Querol et al., 2009; Kanakidou et al., 2011). The excessive amounts of aerosol solar absorption ( $>30-40 \mathrm{~W} \mathrm{~m}^{-2}$ ) over the Middle-East and North Africa (yellow and reddish colours, Fig. 1ii), apart from high amounts of solar radiation and aerosol (dust) AOD, and relatively small cloudiness and precipitation, are partly attributed to the low $\omega_{\text {aer }}$ values there (down to 0.88 at $550 \mathrm{~nm}$ ). Increasing $\omega_{\text {aer }}$ by $10 \%$, results in a decrease in the computed $\mathrm{DRE}_{\text {atm }}$ values over these areas by $22-29 \mathrm{~W} \mathrm{~m}^{-2}$.

On a seasonal basis, the $\mathrm{DRE}_{\mathrm{atm}}$ values are even stronger. In summer, the regional mean value is equal to $17.5 \mathrm{~W} \mathrm{~m}^{-2}$ (Table 1) whereas local values exceed $100 \mathrm{~W} \mathrm{~m}^{-2}$ (over Africa and the Middle East) mainly during summer, but also in spring (Figs. S3iii and S2ii, respectively, in the Supplement). On the other hand, in winter $D_{R E} E_{a t m}$ decreases down to $4.5 \mathrm{~W} \mathrm{~m}^{-2}$, showing again that $\mathrm{DRE}_{\mathrm{atm}}$ is strongly dependent on the available solar radiation, and certainly more than on AOD. Indeed, the computed ratio $\mathrm{DRE}_{\mathrm{atm}}$-summer/DRE $\mathrm{atm}$-winter (equal to 3.9) is roughly double the corresponding ratio of seasonal AODs (AOD ${ }_{550^{-}}$ summer/AOD 550 -winter equal to about 2). It is interesting to note the local maxima of $\mathrm{DRE}_{\text {atm }}$ (about $15-20 \mathrm{~W} \mathrm{~m}^{-2}$, Fig. S3i, S3ii in the Supplement) computed for central and northern Europe only in winter and spring that can be attributed to absorbing aerosols from local anthropogenic activities. AOD is relatively high there, up to $0.2-0.25$, whereas single scattering albedo is relatively low, down to 0.85-0.9. These aerosols are known to be transported towards the Arctic and constitute the Arctic haze.

A similarly good agreement to that for $\mathrm{DRE}_{\mathrm{TOA}}$ is obtained comparing our model $\mathrm{DRE}_{\text {atm }}$ values against other 
independent estimates for specific Mediterranean sites. Thus, for Lampedusa island, the $\mathrm{DRE}_{\text {atm }}$ values for equinox and summer solstice reported by di Biagio et al. (2010) are equal to 8.2 and $10.7 \mathrm{~W} \mathrm{~m}^{-2}$, comparable to our values of 9.5 and $14 \mathrm{~W} \mathrm{~m}^{-2}$, respectively. For Crete island, Markowicz et al. (2002) reported a summer $\mathrm{DRE}_{\mathrm{atm}}$ value of $11.3 \mathrm{~W} \mathrm{~m}^{-2}$, which is again quite close to our corresponding value of $8.6 \mathrm{~W} \mathrm{~m}^{-2}$.

\subsubsection{DRE $_{\text {surf }}$ and DRE netsurf $_{\text {f }}$}

Aerosols, through scattering and absorption, decrease drastically the downwelling $\left(\mathrm{DRE}_{\text {surf }}\right)$ and absorbed $\left(\mathrm{DRE}_{\text {netsurf }}\right)$ solar radiation at the Mediterranean surface, by 16.5 and $13.5 \mathrm{~W} \mathrm{~m}^{-2}$, respectively (Table 1 ), on an annual mean basis, producing thus an important surface radiative cooling. A stronger aerosol induced surface radiative cooling is estimated over land $\left(-18.2\right.$ and $\left.-13.9 \mathrm{~W} \mathrm{~m}^{-2}\right)$ than ocean $\left(-12.2\right.$ and $\left.-11.4 \mathrm{~W} \mathrm{~m}^{-2}\right)$, becoming even stronger over deserts, with values equal to -31.6 and $-21.7 \mathrm{~W} \mathrm{~m}^{-2}$. This regional aerosol surface cooling is significant (about 15\%) as compared to the downward and absorbed solar radiation at the region's surface $\left(172.4 \pm 1.8\right.$ and $147.0 \pm 1.7 \mathrm{~W} \mathrm{~m}^{-2}$, respectively). The patterns of $\mathrm{DRE}_{\text {surf }}$ and $\mathrm{DRE}_{\text {netsurf }}$ are very similar, and thus only the latter is shown in Fig. 1iii. The largest (absolute) values are found over the deserts of Middle East and North Africa, where the surface solar absorption is decreased by $25-55 \mathrm{~W} \mathrm{~m}^{-2}(19-60 \%)$. Smaller, though still important DRE $E_{\text {netsurf }}$ values $\left(12-15 \mathrm{~W} \mathrm{~m}^{-2}\right)$ are found over the Mediterranean Sea, whereas values $<10 \mathrm{~W} \mathrm{~m}^{-2}$ are found over the European continent. On a seasonal basis,

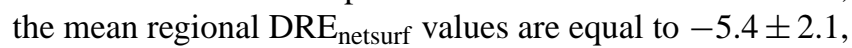
$-17.1 \pm 3.2,-21.8 \pm 0.9$, and $-9.6 \pm 4.6 \mathrm{~W} \mathrm{~m}^{-2}$ for winter, spring, summer, and autumn, respectively (Table 1). Nevertheless, the values are much larger at the $2.5^{\circ} \times 2.5^{\circ}$ grid cell level, rising up to $90 \mathrm{~W} \mathrm{~m}^{-2}$ in summer (Fig. S4iii, see Supplement). In general, the seasonal patterns of $\mathrm{DRE}_{\text {netsurf }}$ are similar to those of $\mathrm{DRE}_{\mathrm{atm}}$ already discussed, for example, they also exhibit the local maximum in central-northern Europe during winter (Fig. S4i, see Supplement). When compared to independent estimates for specific Mediterranean sites, our results reveal, as already seen at TOA and in the atmosphere, a reasonably good comparison. For example, the $\mathrm{DRE}_{\text {surf }}$ values for Lampedusa island are equal to $-12.5 \mathrm{~W} \mathrm{~m}^{-2}$ for equinox and $-16 \mathrm{~W} \mathrm{~m}^{-2}$ for summer solstice (see di Biagio et al., 2010), against our respective values of -20.1 and $-27.6 \mathrm{~W} \mathrm{~m}^{-2}$.

Given that DRETOA primarily depends on aerosol scat-

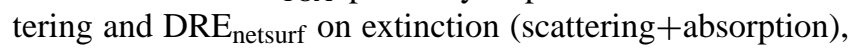
their ratio, $\mathrm{DRE}_{\mathrm{TOA}} / \mathrm{DRE}_{\text {netsurf }}$ is a good indicator of aerosol absorption. Aerosol single scattering albedo is of course another indicator, but it describes just the absorption efficiency. It does not measure the actual absorption of solar radiation by the aerosols present in the atmosphere, which is better described by the ratio $\mathrm{DRE}_{\mathrm{TOA}} / \mathrm{DRE}_{\text {netsurf }}$.
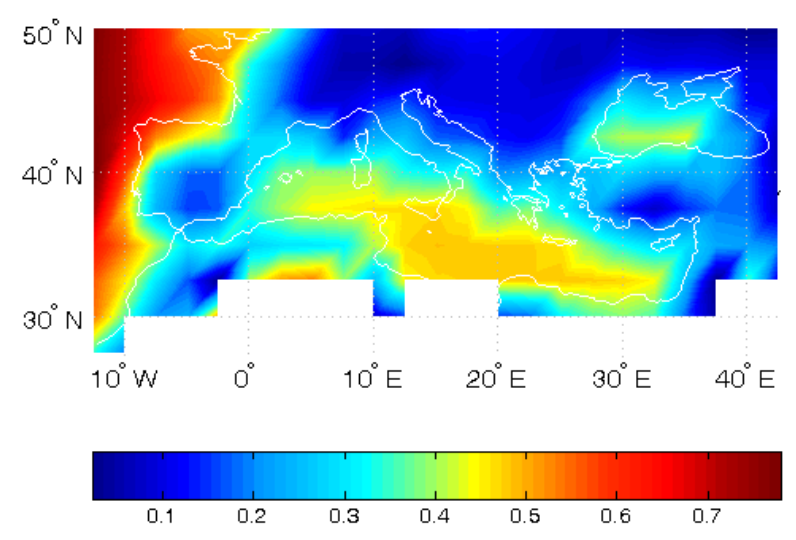

(i)

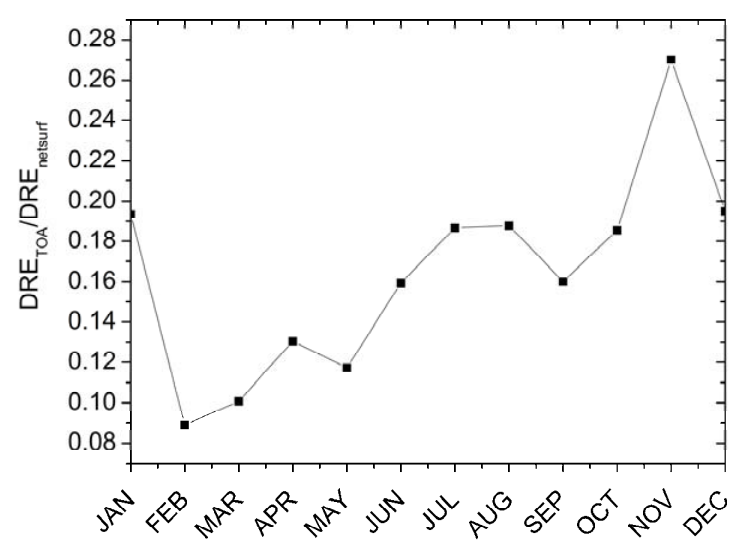

(ii)

Fig. 2. (i) Seven-year average (2000-2007) spatial distribution of the ratio $\mathrm{DRE}_{\mathrm{TOA}} / \mathrm{DRE}_{\text {netsurf }}$ over the broader Mediterranean region, and (ii) seasonal variation of the 7-yr mean regional $\mathrm{DRE}_{\mathrm{TOA}} / \mathrm{DRE}_{\text {netsurf values. }}$

When it takes values close to 1.0, aerosols are almost pure scatterers, while strongly absorbing aerosols are char-

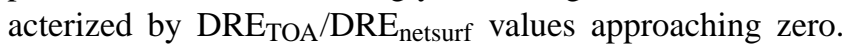
Figure 2i displays the 7-yr average spatial distribution of $\mathrm{DRE}_{\mathrm{TOA}} / \mathrm{DRE}_{\text {netsurf }}$ ratio. Over the seas, the ratio values are higher than 0.5, associated with the presence of scattering sea-salt aerosols, while over land the ratio takes values smaller than 0.2 indicating more absorbing continental aerosols. The computed mean regional ratio $\mathrm{DRE}_{\mathrm{TOA}} / \mathrm{DRE}_{\text {netsurf }}$ is equal to 0.18 , indicating the presence of strongly absorbing aerosols over the Mediterranean basin. Figure 2ii shows the seasonal variation of regional mean $\mathrm{DRE}_{\mathrm{TOA}} / \mathrm{DRE}_{\text {netsurf values. Relatively smaller values }}$ $(0.09-0.16)$ are found in spring and early autumn (September), associated with the presence of absorbing aerosols, mainly dust, spread out over extended areas of the Mediterranean basin, even reaching northern Europe, under frequently occurring southerly cyclonic circulation. The low ratios, especially over European continental areas, can be also attributed to absorbing aerosols, which are mostly 
emitted by anthropogenic activities over European continental areas, as already reported in Sect. 3.2.2. Larger $\mathrm{DRE}_{\mathrm{TOA}} / \mathrm{DRE}_{\text {netsurf }}$ values are seen in summer and winter $(0.19-0.27)$ owing to the contribution of scattering, mainly anthropogenic, aerosols emitted in Europe and subsequently transported southwards through favourable anticyclonic circulation (e.g. Azores anticyclone in summer). The large winter $\mathrm{DRE}_{\mathrm{TOA}} / \mathrm{DRE}_{\text {netsurf }}$ values (peak in November) might be associated with the efficient wash-out of aerosols by rain, which is maximum during this season in the Mediterranean, controlled thus by the influence of regional/local emissions, composed mainly by sea-salt and sulfate aerosols.

The significant SSR reduction induced by aerosols translates to a surface cooling that, according to our computations, can be as large as $-0.029 \mathrm{~K} \mathrm{day}^{-1}$ over the Mediterranean Sea, and up to $-2.04 \mathrm{~K} /$ day over North Africa. Such a large surface cooling, together with the significant atmospheric warming of up to $0.22 \mathrm{Kday}^{-1}$ over the Mediterranean Sea and $2.2 \mathrm{Kday}^{-1}$ over North Africa, can influence the regional atmospheric dynamics by decreasing the atmospheric temperature gradient, thus leading to more stable atmospheric conditions. This can have important implications for the region's climate (e.g. possible effects on clouds and precipitation) in view of the changing aerosol loadings and composition observed over the Mediterranean basin on decadal timescales (e.g. Perez et al., 2008; Papadimas et al., 2008; Koukouli et al., 2009).

\subsection{Aerosol radiative efficiency}

Aerosol DREs strongly depend on AOD, apart from other parameters like the available solar flux itself (e.g. Hatzianastassiou et al., 2004b). The dependence of DRE on AOD is here investigated by means of aerosol radiative efficiency, i.e. the aerosol perturbation of solar radiation, at TOA, in the atmosphere and at the surface $\left(\mathrm{E}_{\mathrm{AOD}, \mathrm{TOA}}, \mathrm{E}_{\mathrm{AOD}, \mathrm{atm}}, \mathrm{E}_{\mathrm{AOD}}\right.$,netsurf, respectively) per unit of optical depth $\left(\mathrm{AOD}_{550}^{-1}\right)$, computed by Eq. (4). The slope of the applied linear regression fit to DRE values as function of $\mathrm{AOD}_{550}$, can be also defined as the radiative efficiency ( $\mathrm{E}_{\mathrm{AOD}}$; Eq. 4). This slope is actually a more robust measure of $\mathrm{E}_{\mathrm{AOD}}$ than the simple ratio (Christopher and Jones, 2008). Therefore, we followed this methodology (linear regression fitting) to estimate the aerosol radiative efficiency in the Mediterranean. The scatterplots, linear fits, and the obtained relationships between $\mathrm{AOD}_{550}$ and $\mathrm{DRE}_{\mathrm{i}}$ can be seen in Fig. 3. The derived relationships enable a rough estimation of aerosol radiative effects over the Mediterranean basin if we know the AOD $_{550}$ value. The larger $\mathrm{E}_{\mathrm{AOD}}$ values at the surface and in the atmosphere, or in other words the larger slopes of linear regression fits, indicate the strong dependence of surface and atmospheric aerosol radiative effects, in absolute terms, on AOD. In contrast, the aerosol effects at TOA, their magnitude in absolute terms, depend much less on AOD. $\mathrm{E}_{\mathrm{AOD}}$ under clear-sky conditions does not significantly change from that under all-sky conditions (see Fig. 3i, ii, iii-b). In all scatterplots, there appears a group of points (red colour) which is separated from the main body of blue points. Although their number is relatively small, $4 \%$ of the total number of points, they seriously affect the applied linear regression fits to the overall population of points. Therefore, linear regression fits have been applied separately to the two groups of points. It is seen that for $\mathrm{E}_{\mathrm{AOD} \text {,atm }}$ and $\mathrm{E}_{\mathrm{AOD} \text {, netsurf the two }}$ linear fit lines are almost parallel, but the intercept is larger (absolute terms) in the case of red points, indicating larger DREs for them. Moreover, for $\mathrm{E}_{\mathrm{AOD}, \mathrm{TOA}}$, the slope changes sign and becomes positive, opposite to the negative slope for blue points. Positive and negative slopes for $\mathrm{E}_{\mathrm{AOD} \text {,TOA }}$ indicate planetary warming and cooling due to aerosols. The performed analysis revealed that red points (planetary warming) correspond to geographical cells that are systematically located in northern Africa, and correspond to absorbing dust aerosols. In all cases however, the obtained linear fit equations indicate that increasing AODs produces amplified mag-

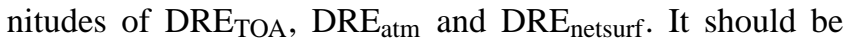
clarified that the applied linear regressions here do not aim to provide estimates of aerosol DREs based on AOD values, but just to determine, through the computed slopes of linear fits, the nature and extent of the dependence of DREs on AOD, over the Mediterranean basin.

When compared to available independent radiative forcing efficiencies for specific Mediterranean sites, our computed

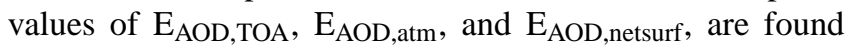
quite similar, which increases the confidence in our model results. Thus, for instance, for Lampedusa island, the $\mathrm{E}_{\mathrm{AOD}}$,TOA values for equinox and summer solstice reported by di Biagio et al. (2010) are equal to $-36.2 \mathrm{~W} \mathrm{~m}^{-2}$ and $-44.2 \mathrm{~W} \mathrm{~m}^{-2}$, respectively. These values are quite close to our corresponding values of $-44.2 \mathrm{~W} \mathrm{~m}^{-2}$ and $-48.6 \mathrm{Wm}^{-2}$. The $\mathrm{E}_{\mathrm{AOD}, \mathrm{TOA}}$ values for Crete island, reported by Vrekoussis et al. (2005), range from $-30 \mathrm{~W} \mathrm{~m}^{-2}$ in winter to $-73 \mathrm{~W} \mathrm{~m}^{-2}$ in summer, compared to our values of -15 and $-50 \mathrm{~W} \mathrm{~m}^{-2}$, respectively. A good comparison is also obtained between our summer $\mathrm{E}_{\mathrm{AOD}, \mathrm{TOA}}$ value of $-45.2 \mathrm{~W} \mathrm{~m}^{-2}$ for Crete island, and the value of $-31.4 \mathrm{~W} \mathrm{~m}^{-2}$ estimated and reported by Markowicz et al. (2002). Similarly good comparisons are obtained for $\mathrm{E}_{\mathrm{AOD} \text {,atm }}$ and $\mathrm{E}_{\mathrm{AOD} \text {, netsurf }}$.

To further examine the impact of aerosols on solar radiation, the aerosol radiation (budget) efficiency (ARBE, Eqs. 5 and 6) has been computed. The $\mathrm{ARBE}_{i}$ values (Fig. 4) indicate above the broader Mediterranean basin, a $1-22 \%$ increase in the outgoing solar radiation (OSR) at TOA due to aerosols under all-sky conditions, with a stronger influence over the Mediterranean Sea and over north Africa (Fig. 4ia). Under all-sky conditions, the aerosol influence is largely dominated by the presence of clouds that have much larger optical depth than aerosols, or by the strong land-surface (desert) reflection. The influence of aerosols is stronger in case of small cloudiness or for massive aerosol loads, like those over deserts. Under clear-sky conditions (Fig. 4i-b) the 


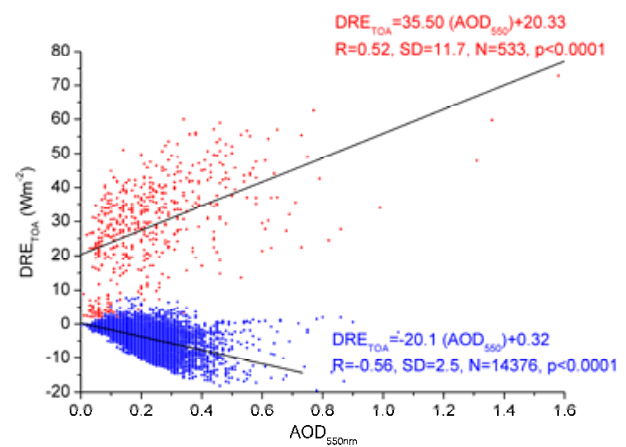

(i-a)

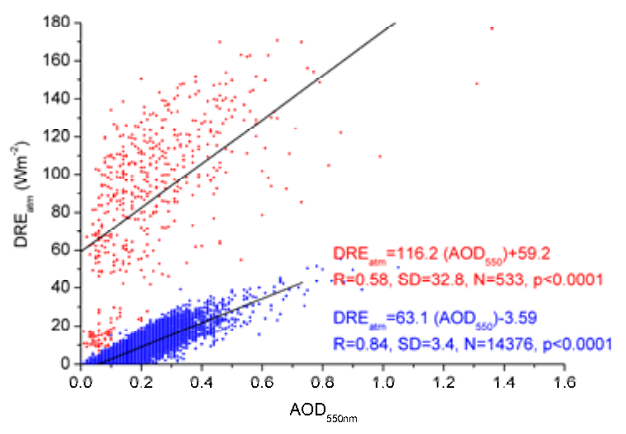

(ii-a)

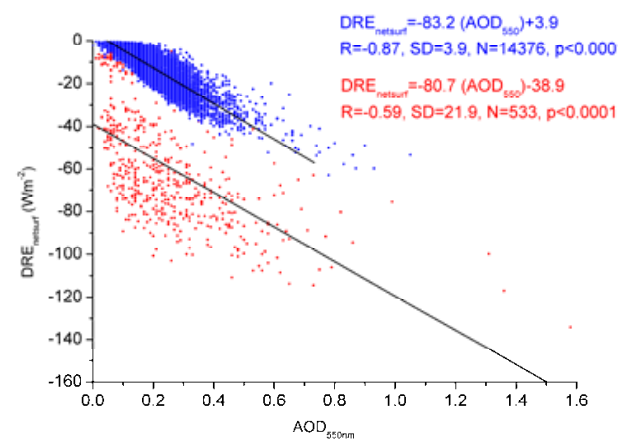

(iii-a)

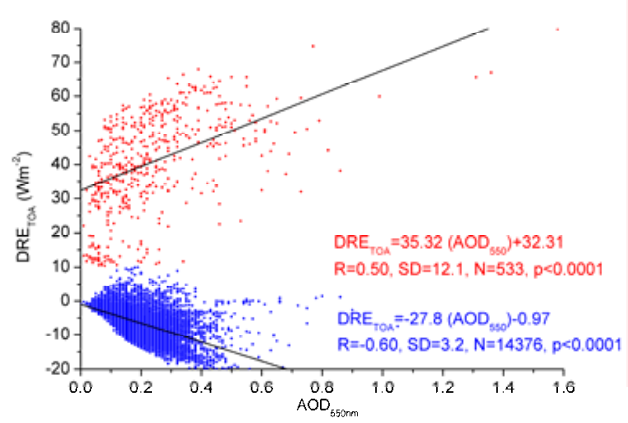

(i-b)

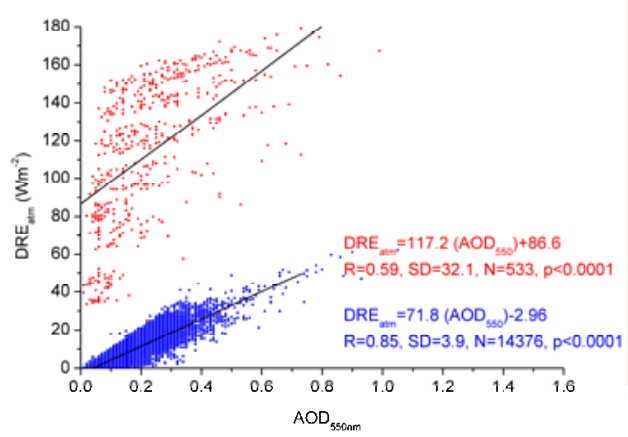

(ii-b)

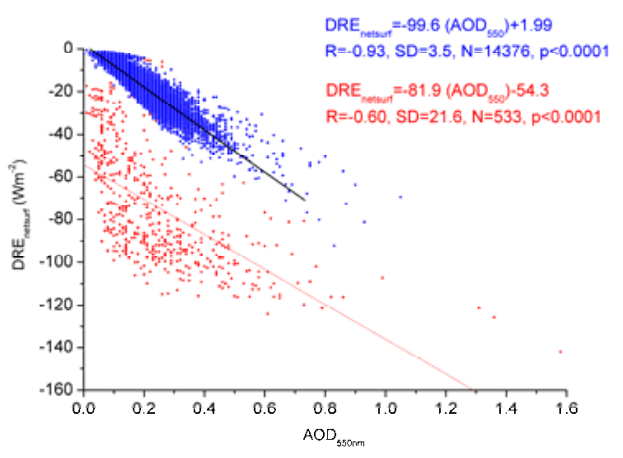

(iii-b)

Fig. 3. Scatterplot comparison between monthly mean DRE and $\mathrm{AOD}_{550}$ values: (i) at TOA, (ii) in the atmosphere and (iii) at surface of the broader Mediterranean basin under: (a) all-sky and (b) clear-sky conditions. Applied linear regression fit lines are also shown, along with the computed slope, intercept and correlation coefficient values, and have been applied separately to the main blue (96\% of total number points) and secondary red (4\% of total number points) groups of points.

aerosol influence is amplified, especially over dark ocean surfaces. For example, see the large increase of ARBETOA over the Atlantic Ocean and Black Sea, while similarly small values are found over the European continent. The ARBE values under clear-sky conditions can be as large as $33 \%$. The modification of solar atmospheric absorption by aerosols above the study region (Fig. 4ii-a, b) is larger than that of reflected radiation to space, with values ranging between 5 and $105 \%$. Values of $10-20 \%$ are computed above extended ar- eas of the study region, whereas they reach 30-100\% above vast desert areas with high aerosol loads ( $\mathrm{AOD}_{550}$ up to 0.4). Similar geographical patterns, but with even higher values $(10-150 \%)$ are computed under clear-sky conditions. The significant effect of aerosols on solar atmospheric absorption over the industrial regions of central Europe can be seen, with values up to $25 \%$ in all-sky and $50 \%$ in clearsky conditions, respectively. Our results highlight the key role of aerosols for solar heating of the region's atmosphere, 


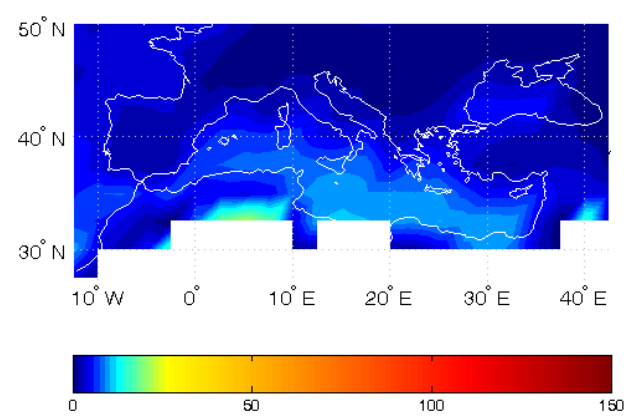

(i-a)

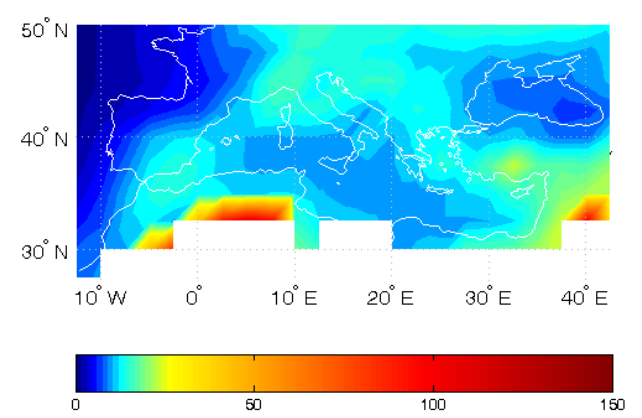

(ii-a)

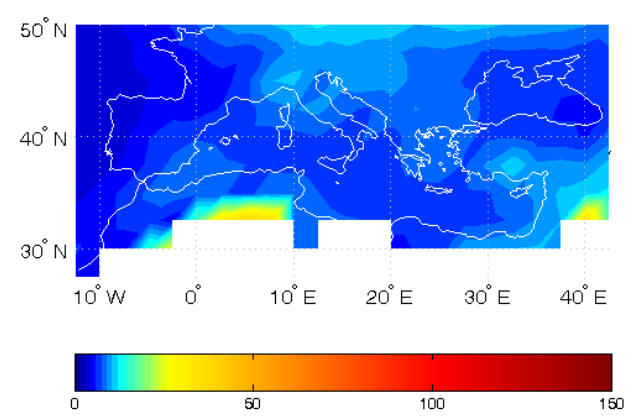

(iii-a)
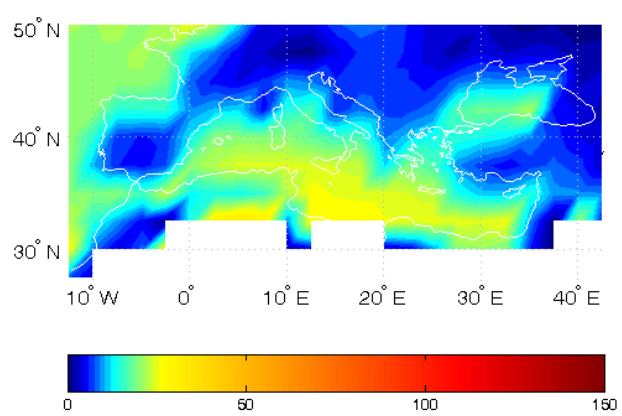

(i-b)

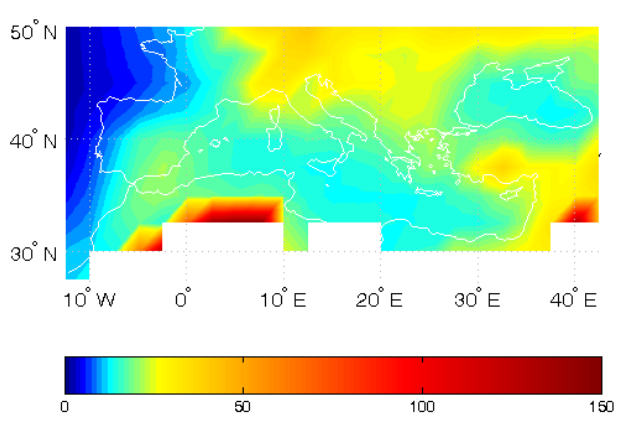

(ii-b)

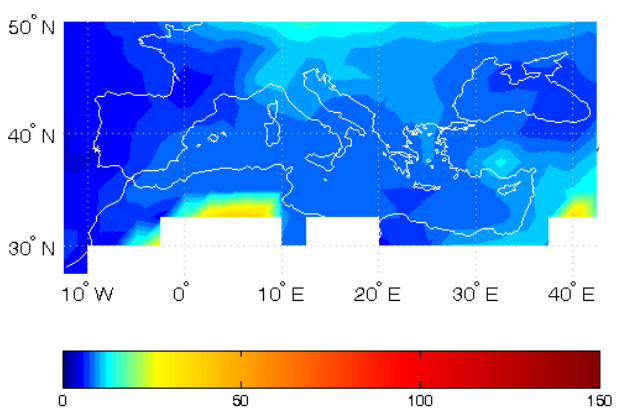

(iii-b)

Fig. 4. Aerosol radiation budget efficiency, namely the percent change in solar radiative fluxes (in \%) due to the presence of aerosols. Results are given at TOA (i), in the atmosphere (ii), and at surface (iii). Results are given separately under: (a) all-sky (a), and (b) clear-sky conditions.

since they can even double it in case of significant absorbing aerosol amounts. Nevertheless, it is worth noting the absence of large $\mathrm{ARBE}_{\text {atm }}$ values over the Mediterranean Sea or the Atlantic Ocean, even under clear-skies, opposite to $\mathrm{ARBE}_{\mathrm{TOA}}$. This indicates the very weak absorption ability of sea-salt or sulphate maritime aerosols.

Aerosols reduce the downward solar radiation at the Mediterranean's surface by 3-38\% under all-sky conditions (Fig. 4iii-a), with the largest percent decrease observed primarily over North Africa, Middle-East and the Anatolian peninsula, and secondarily over central and northern Europe. Under clear-sky conditions, the geographical patterns of $\mathrm{ARBE}_{\text {surf }}$ remain about the same with those in case of allsky, but the values are higher by about $25 \%$.

Figure 4 reveals the significant role of aerosols in modifying the solar radiation budget of the Mediterranean basin, inducing important changes in the solar radiative fluxes at TOA, in the atmosphere, and at the region's surface. Yet, our results suggest that this role becomes even more important in the case of solar atmospheric absorption. 


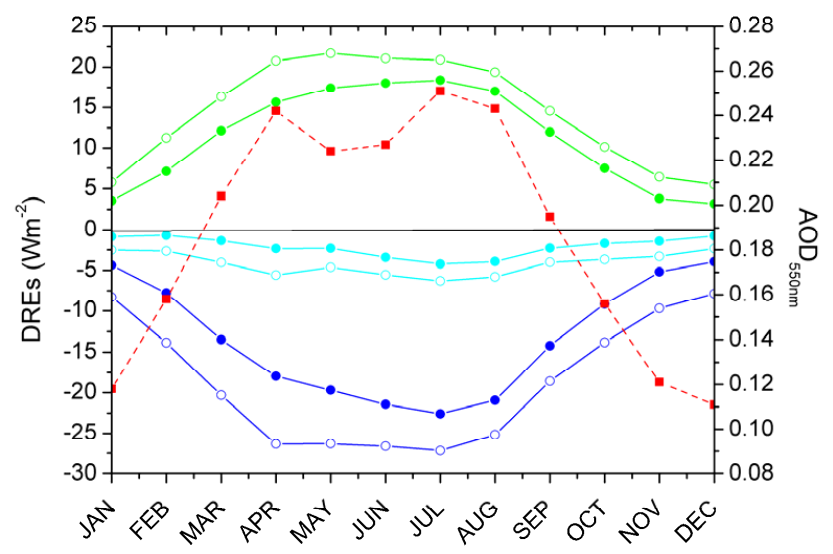

Fig. 5. Intra-annual variation of seven-year (2000-2007) regional mean values of aerosol DREs (at TOA: DRETOA cyan lines, in the atmosphere: $\mathrm{DRE}_{\text {atm }}$ green lines, at surface: $\mathrm{DRE}_{\text {netsurf }}$ blue lines) under all-sky (full circles) and clear-sky (open circles) conditions. The intra-annual variation of visible $\mathrm{AOD}_{550}$ (dashed red line, rectangles) is also given (right $\mathrm{y}$-axis).

\subsection{Seasonal and inter-annual variation of aerosol DREs}

Figure 5 shows the seasonal variation of aerosol DREs for the Mediterranean basin under all-sky and clear-sky conditions separately. For all-sky conditions, negative and positive values of DRE $E_{\text {netsurf }}$ and $D_{\text {RE }}$ atm, respectively, indicate that in the Mediterranean, aerosols reduce the absorbed solar radiation at the surface, $\mathrm{DRE}_{\text {netsurf }}$, by $3.9-22.6 \mathrm{~W} \mathrm{~m}^{-2}$, and enhance the absorbed solar radiation within the atmosphere, $\mathrm{DRE}_{\text {atm }}$, by $3.2-18.4 \mathrm{~W} \mathrm{~m}^{-2}$. Hence, $\mathrm{DRE}_{\text {netsurf }}$ and $\mathrm{DRE}_{\text {atm }}$ exhibit significant seasonal variations, in contrast to DRE $_{T O A}$ that shows weak seasonal variation (or cycle, between -0.7 and $-4.2 \mathrm{~W} \mathrm{~m}^{-2}$ ). The maximum aerosol radiative effects are observed in summer and spring, and the minimum in winter, following thus the seasonal variation of the corresponding solar radiation fluxes, but also of the aerosol loading (AOD 550 , seasonal cycle shown in Fig. 5).

The role of cloudiness for aerosol DREs can be assessed by comparing the results of Fig. 5 for all- and clear- skies. As expected, the clear-sky DREs absolute values are consistently larger than the all-sky ones. DRE $E_{\text {netsurf is reaching }}$ about $27 \mathrm{~W} \mathrm{~m}^{-2}$ and presents clear maxima in summer and spring, reflecting primarily the seasonality of the available solar radiation fluxes and secondarily that of AOD. The role of AOD is strengthened in the absence of clouds, as shown by the significant spring peaks that appear in clear-sky conditions for all DRE components.

The time-series of regional mean aerosol DREs are displayed in Fig. 6. All-sky DRETOA (Fig. 6a) exhibits an annual cycle with clear maximum absolute values in summer (see also Fig. 5) when it ranges between -4.0 and $-5.5 \mathrm{~W} \mathrm{~m}^{-2}$, and minimum values in winter DRE $_{\mathrm{TOA}}$ be-

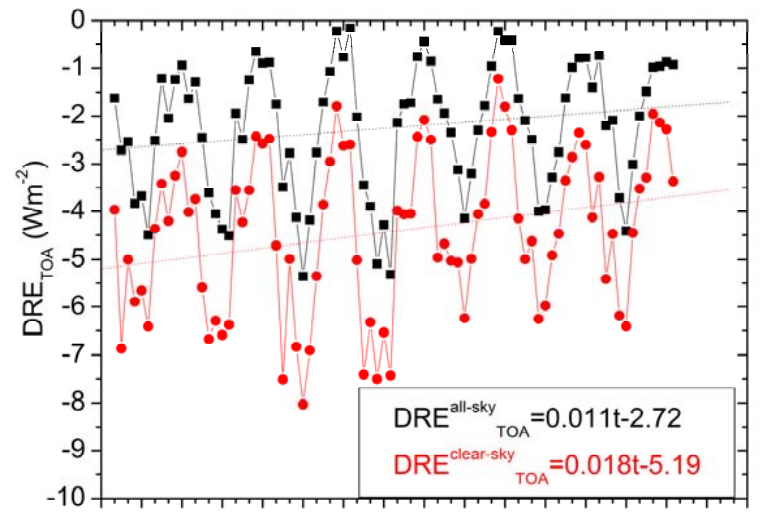

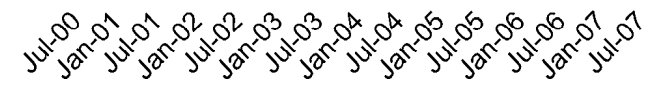

(a)

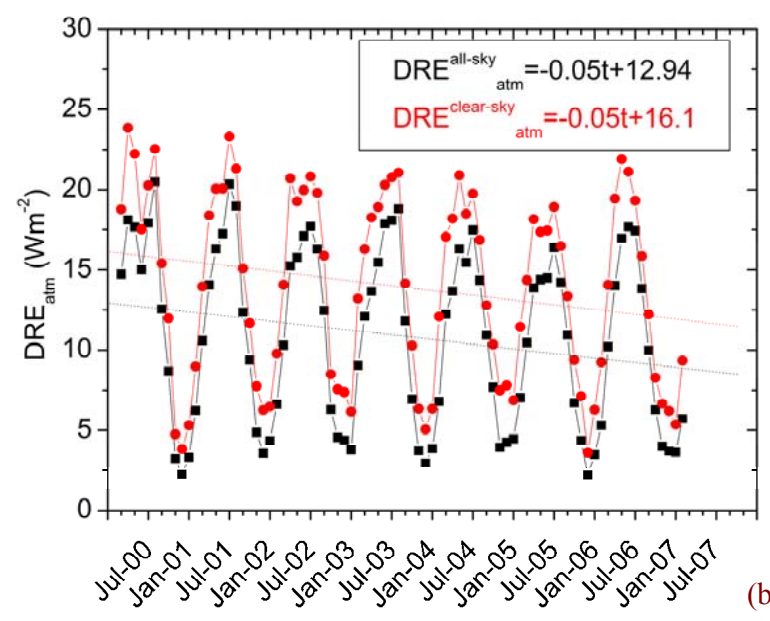

(b)

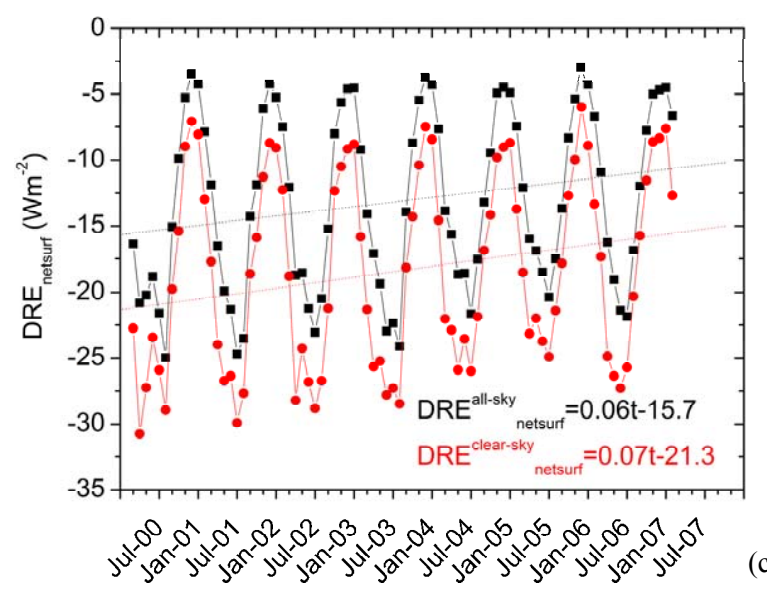

(c)

Fig. 6. Time series (2000-2007) of mean regional monthly values of: (a) $\mathrm{DRE}_{\mathrm{TOA}}$, (b) $\mathrm{DRE}_{\mathrm{atm}}$ and (c) $\mathrm{DRE}_{\text {netsurf }}$ (in $\mathrm{W} \mathrm{m}^{-2}$ ) for the broader Mediterranean basin, under all-sky (black lines) and clearsky (red lines) conditions. Linear regression fit lines and the associated equations ( $t$ is the number of month starting from March 2000) are also shown. 
tween 0 and $-0.9 \mathrm{~W} \mathrm{~m}^{-2}$ ). There is, however, a significant year-to-year variability, in terms of both maximum and minimum values. For example, the summer values of 2002 and 2003 are larger (in absolute terms) by about $1 \mathrm{~W} \mathrm{~m}^{-2}$ than those of other years, while the winter values of 2003 and 2005 are very close to zero. Under clear-sky conditions, the magnitude of $\mathrm{DRE}_{\mathrm{TOA}}$ is consistently larger, with a secondary peak in spring (mainly in April) reflecting the AOD seasonality as earlier discussed. The inter-annual variation of $\mathrm{DRE}_{\mathrm{atm}}$ and $\mathrm{DRE}_{\text {netsurf }}$ is smoother than $\mathrm{DRE}_{\mathrm{TOA}}$, with maximum and minimum absolute values observed in summer and winter, respectively, regardless of sky conditions. $D_{\text {DRE }}$ atm values vary within the range $2-24 \mathrm{~W} \mathrm{~m}^{-2}$, with slightly (by about $2-3 \mathrm{~W} \mathrm{~m}^{-2}$ ) larger magnitude under clearskies, whereas the DRE $E_{\text {netsurf }}$ regional mean values range from -2.7 to $-31 \mathrm{~W} \mathrm{~m}^{-2}$ over the period 2000-2007 again being larger (by up to about $6 \mathrm{~W} \mathrm{~m}^{-2}$ ) under clear-sky than under all-sky conditions.

Given that aerosol properties are changing with time (e.g. Mischenko et al. 2007; Perez et al., 2008; Papadimas et al., 2008) it is expected that aerosol radiative effects, DREs, are also subject to variations with time. Such variations produce modifications of solar radiation that contribute to the overall solar radiation changes (solar dimming and brightening when referring to the Earth's surface) that, apart from aerosols, are also produced by other parameters of the Earth-atmosphere system, namely clouds, water vapour or other trace gases. Here, we attempted to estimate the aerosol-induced interannual changes of solar radiation in the Mediterranean basin over the study period, by applying linear regression fits to the 7-yr time series of deseasonalized anomalies of DRE components (Fig. S5). Our results indicate that $\mathrm{DRE}_{\text {netsurf }}$ has decreased in magnitude by $2.48 \mathrm{~W} \mathrm{~m}^{-2}$ (or by $18.4 \%$ ) from 2000 to 2007, resulting thus in an equivalent increase of surface solar radiation. According to our results, decreases of DRE $_{\text {netsurf }}$ are calculated for all seasons, as shown in Table S5 of the Supplement. Over the same period, the surface solar radiation over the broader Mediterranean basin has decreased by $25.6 \mathrm{~W} \mathrm{~m}^{-2}$. Therefore, it appears that the aerosol induced increase in surface solar radiation has been overwhelmed by the decrease produced by the other parameters. Indeed, ISCCP data analysis shows an increase in cloudiness over the Mediterranean from 2000 to 2007 equal to $7 \%$, and a corresponding increase in total precipitable water by $5.6 \%$

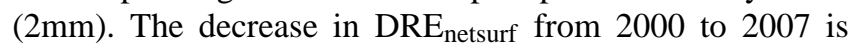
almost identical under clear- and all-sky conditions, which means that it is not related to clouds, but to the regional aerosol loading. Indeed, over the same period $\mathrm{AOD}_{550}$ has decreased by 0.05 or by $27 \%$, in line with the reduced emissions of aerosols and aerosol precursors, but also with the increased aerosol removal by enhanced precipitation (see $\mathrm{Pa}$ padimas et al., 2008).

\section{Sensitivity of aerosol DREs}

Despite the considerable number of past studies (e.g. Koepke and Hess, 1988; Charlson et al., 1992; Penner et al., 1994; Hansen et al., 1997; Haywood and Shine, 1997; Schult et al., 1997; Penner et al., 1998; Haywood and Ramaswamy, 1998; Myhre et al., 1998; Ramanathan et al., 2001; Yu et al., 2006; Hatzianastassiou et al., 2004a,b; 2007a) the magnitude of aerosol radiative effects and forcing, is still uncertain (IPCC, 2007). This uncertainty is largely attributed to the aerosol properties used as input data in the radiation transfer and climate models. Among these aerosol properties, the most important are AOD, $g_{\text {aer }}$ and $\omega_{\text {aer }}$. Therefore, a series of sensitivity tests were performed with our model to assess the uncertainty of the obtained DREs, due to possible inaccuracies of the input AOD, $g_{\text {aer }}$ and $\omega_{\text {aer }}$ data used.

The results of the sensitivity tests are given in terms of absolute and percentage changes of DREs (Eqs. 8 and 9 , respectively $)$, denoted as $\Delta\left(\mathrm{DRE}_{\mathrm{i}}\right)$ and $\Delta\left(\mathrm{DRE}_{\mathrm{i}}\right) \%$ respectively, and defined as

$\Delta\left(\mathrm{DRE}_{\mathrm{i}}\right)=\mathrm{DRE}_{\mathrm{i}}-\mathrm{DRE}_{\mathrm{ref}, \mathrm{i}}$

$\Delta\left(\mathrm{DRE}_{\mathrm{i}}\right) \%=\frac{\mathrm{DRE}_{\mathrm{i}}-\mathrm{DRE}_{\mathrm{ref}, \mathrm{i}}}{\mathrm{DRE}_{\mathrm{ref}, \mathrm{i}}} \cdot 100$

where $\mathrm{DRE}_{\text {ref,i }}$ are the aerosol DREs for the reference simulation and $\mathrm{DRE}_{\mathrm{i}}$ are the corresponding DREs for each sensitivity simulation. The reference DREs are those for the year 2003. Their annual regional mean values, namely $\mathrm{DRE}_{\text {ref,TOA, }}, \mathrm{DRE}_{\text {ref,atm }}$, and DRE $\mathrm{ref}_{\text {,surf, }}$ are equal to -2.6 , 11.2 and $-16.9 \mathrm{~W} \mathrm{~m}^{-2}$, respectively (Table 3 ).

To examine the sensitivity of the reference DREs to the uncertainty of the three aerosol optical properties, we have increased and decreased each one of them by $10 \%$, and computed the resulting changes in $\mathrm{DRE}_{\mathrm{i}}, \Delta\left(\mathrm{DRE}_{\mathrm{i}}\right)$, that are given in Table 3. It should be clarified that the selected magnitude of changes in AOD, $\omega_{\text {aer }}$, and $g_{\text {aer }}$, i.e. $\pm 10 \%$, was chosen just to examine the relative sensitivity of various model aerosol DREs to the same change of each one of the three key model aerosol optical properties. In other words, it was chosen in terms of a comparative study, and does not imply that such a change is realistic but only nominal. Increasing/decreasing AOD by $10 \%$ resulted in an increase/decrease of all DRE components. More specifically, DRE $_{\mathrm{TOA}}$ has increased by $8.4 \%, \mathrm{DRE}_{\mathrm{atm}}$ by $9.3 \%$ and $\mathrm{DRE}_{\text {surf }}$ by $9 \%$. So, it appears that aerosol DRE at TOA, surface and in the atmosphere, show similar sensitivity to variations of AOD. Therefore, the slight $(1 \%)$ underestimation of MODIS C005 AOD used in our modelling study (with respect to AERONET, see Sect. 2.2) as evaluated by Papadimas et al. (2009), induces a smaller than $1 \%$ underestimation of the computed DREs discussed in Sect. 3. Based on these sensitivity tests the impact of possible current or future variability of natural or anthropogenic AOD in the Mediterranean 
Table 3. Modifications $\Delta\left(\mathrm{DRE}_{\mathrm{i}}\right)$ of reference model annual aerosol $\mathrm{DRE}_{\mathrm{ref}, \mathrm{i}}$ (in $\mathrm{W} \mathrm{m}^{-2}$ and $\%$ ) for the broader Mediterranean region, arising from variations of $\mathrm{AOD}$, single scattering albedo $\left(\omega_{\mathrm{aer}}\right)$, and asymmetry parameter $\left(g_{\text {aer }}\right)$, equal to $\pm 10 \%$. The reference aerosol DRE $\mathrm{ref}, \mathrm{i}$ (in $\mathrm{W} \mathrm{m}^{-2}$ ) for the year 2003 are also given below.

\begin{tabular}{|c|c|c|c|c|c|c|c|c|c|c|c|c|}
\hline \multirow{3}{*}{$\Delta \mathrm{V}(\%)$} & \multicolumn{4}{|c|}{$\Delta(\mathrm{DRE})_{\mathrm{TOA}}$} & \multicolumn{4}{|c|}{$\Delta(\mathrm{DRE})_{\mathrm{atm}}$} & \multicolumn{4}{|c|}{$\Delta(\mathrm{DRE})_{\text {surf }}$} \\
\hline & \multicolumn{2}{|c|}{+10} & \multicolumn{2}{|c|}{-10} & \multicolumn{2}{|c|}{+10} & \multicolumn{2}{|c|}{-10} & \multicolumn{2}{|c|}{+10} & \multicolumn{2}{|c|}{-10} \\
\hline & $\mathrm{W} \mathrm{m}^{-2}$ & $\%$ & $\mathrm{~W} \mathrm{~m}^{-2}$ & $\%$ & $\mathrm{~W} \mathrm{~m}^{-2}$ & $\%$ & $\mathrm{~W} \mathrm{~m}^{-2}$ & $\%$ & $\mathrm{~W} \mathrm{~m}^{-2}$ & $\%$ & $\mathrm{~W} \mathrm{~m}^{-2}$ & $\%$ \\
\hline AOD & -0.22 & 8.4 & 0.22 & -8.4 & 1.04 & 9.3 & -1.05 & -9.4 & -1.52 & 9.0 & 1.54 & -9.1 \\
\hline$\omega_{\mathbf{a e r}}$ & -0.99 & 37.9 & 1.12 & -42.9 & -8.22 & -73.4 & 7.60 & 67.9 & 5.78 & -34.2 & -6.46 & 38.2 \\
\hline$g_{\text {aer }}$ & 0.79 & -30.3 & -0.76 & 29.3 & -0.07 & -0.6 & 0.07 & 0.6 & 1.64 & -9.7 & -1.57 & 9.3 \\
\hline DRE $_{\text {ref,TOA }}$ & $\mathrm{DRE}_{\mathrm{ref}, \mathrm{atm}}$ & DRE $_{\text {ref,surf }}$ & & & & & & & & & & \\
\hline-2.6 & 11.2 & -16.9 & & & & & & & & & & \\
\hline
\end{tabular}

can be estimated. For example, increased AOD values due to increased anthropogenic emissions would result in enhanced surface cooling over the region, arising from enhanced reflection to space and atmospheric absorption. The opposite effect, surface warming along with atmospheric cooling, is expected for decreased AOD values that, for example, might result from actions that aim to reduce aerosol emissions, like the Air Framework Directive or the Clean Air for Europe Programme.

Furthermore, a similar to AOD percent increase/decrease in $\omega_{\text {aer }}$, i.e. by $\pm 10 \%$, results in significantly stronger variations of aerosol DREs. As expected, the biggest effect is on aerosol atmospheric warming ( $\left.\mathrm{DRE}_{\mathrm{atm}}\right)$, which is modified by up to about $\pm 70 \%$, whereas the effects on DREs at TOA and surface are smaller (up to about $\pm 40 \%$ ) though still very important. Therefore, possible future changes in $\omega_{\text {aer }}$, as for example smaller $\omega_{\text {aer }}$ values associated with increasing anthropogenic or natural biomass burning activities or increasing emissions of black carbon, may lead to enhanced atmospheric heating, combined with a strengthened surface cooling. These effects may be even stronger if they are accompanied by increased AOD levels. In this case, sensitivity tests performed with the RTM have shown that the effects of modifying $\omega_{\text {aer }}$ and AOD on DRE should be additive.

On the other hand, increasing/decreasing the aerosol asymmetry parameter by $10 \%$, mostly affected the DRE $\mathrm{TOA}_{\mathrm{TO}}$ (by about $30 \%$ ). DRE surf is modified by about $10 \%$ while $\mathrm{DRE}_{\mathrm{atm}}$ is practically unaffected, as expected, given that changing $g_{\text {aer }}$ does not affect the absorption ability of aerosol particles, it only modifies the angular distribution of scattered solar radiation.

Variations of aerosol optical properties by up to $10 \%$, as examined above, are probably realistic only for AOD. For example, AOD is found to have decreased over the Mediterranean basin by about $20 \%$ from 2000 to 2007 (see e.g. Papadimas et al., 2008). In contrast, similar changes in $\omega_{\text {aer }}$ and $g_{\text {aer }}$, associated with anthropogenic or natural variability, are quite difficult to take place on decadal timescales based on the observed range of values of these parameters accounting for their spatial and temporal variability; they rather represent the upper bound of possible natural or anthropogenic variability. Therefore, the sensitivity of model DREs to smaller changes of aerosol optical properties as well has been further examined. For this, AOD, $\omega_{\text {aer }}$ and $g_{\text {aer }}$ have been modified by smaller amounts and the $\Delta\left(\mathrm{DRE}_{\mathrm{i}}\right) \mathrm{s}$ have been re-computed. Note that only one parameter has been changed for each simulation. Nevertheless, as indicated previously, the effects of changing the aerosol optical properties are additive. In Fig. 7 , the computed $\Delta\left(\mathrm{DRE}_{\mathrm{i}}\right)$ values are plotted as function of changing aerosol properties (AOD, $\omega_{\text {aer }}$ and $\left.g_{\text {aer }}\right)$ by $\pm 1, \pm 3, \pm 5, \pm 7$ and $\pm 10 \%$ for the 30 performed simulations. The results are given, again, in terms of regional means for the year 2003. Figure 7 offers the possibility to estimate the modification/dependence of aerosol DREs due to realistic changes of AOD, $\omega_{\text {aer }}$ and $g_{\text {aer }}$. It appears that aerosol DREs over the broader Mediterranean basin, depend almost linearly on changing aerosol optical properties (correlation coefficients of linear regression fits ranging from 0.989 to 1). The derived relationships (Fig. 7) enable an easy, first, estimate of the expected aerosol effects on the regional solar radiation budget, arising from potential changes of aerosol optical properties in various future climatic scenarios.

\section{Discussion of model DRE uncertainties}

The accuracy of model DRE values computed in this study is subject to the uncertainties of MODIS aerosol optical properties used as model input data. These uncertainties, as evaluated through comparisons against ground reference measurements from AERONET stations, are (in absolute/percentage terms) equal to $-2.3 \times 10^{-4}(-0.11 \%)$ for AOD (underestimation), $-0.028(-3 \%)$ for $\omega_{\text {aer }}$ (underestimation), and $-0.031(-4 \%)$ for $g_{\text {aer }}$ (underestimation). These values, used in the derived relationships between $\Delta\left(\mathrm{DRE}_{\mathrm{i}}\right)$ and $\Delta(\mathrm{AOD}), \Delta\left(\omega_{\mathrm{aer}}\right), \Delta\left(g_{\text {aer }}\right)($ Fig. 7$)$ yield uncertainties equal to: (i) $-0.07 \%,-0.11 \%$, and $-0.12 \%$, for

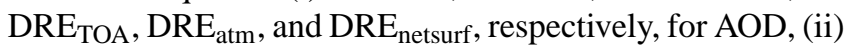



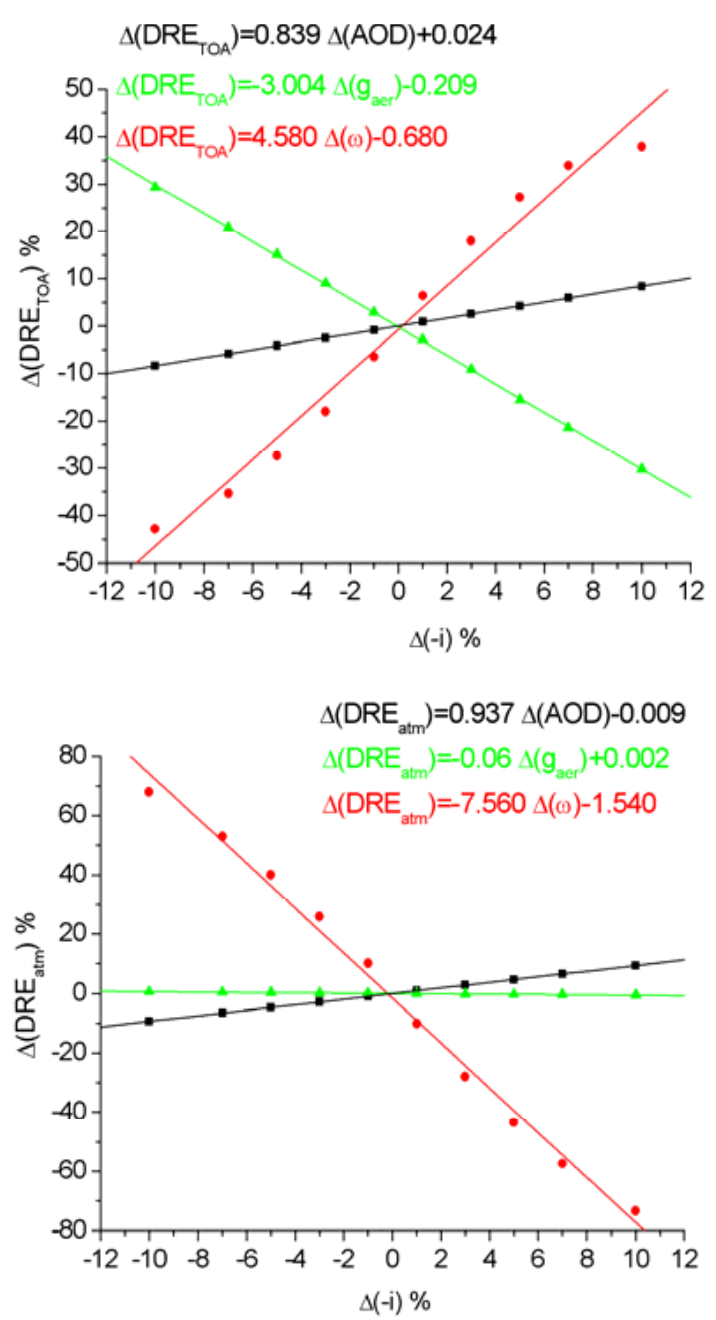

(ii)

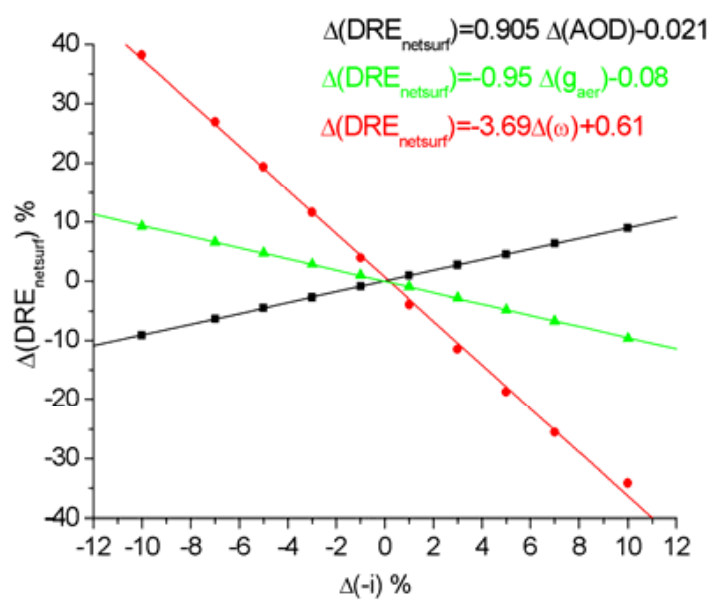

(iii)

Fig. 7. Modifications of aerosol radiative effects: (i) at TOA, $\Delta\left(\mathrm{DRE}_{\mathrm{TOA}}\right)$, (ii) in the atmosphere, $\Delta\left(\mathrm{DRE}_{\mathrm{atm}}\right)$, and (iii) at surface, $\Delta\left(D R E_{\text {surf }}\right)$, as function of changing AOD (black points and fitted lines), $\omega_{\text {aer }}$ (red points and fitted lines), and $g_{\text {aer }}$, (green points and fitted lines), by $\pm 1, \pm 3, \pm 5, \pm 7$ and $\pm 10 \%$. Results are given in terms of regional means for the year 2003 .
$-14.42 \%, 21.14 \%$ and $11.68 \%$ for DRETOA, $\mathrm{DRE}_{\text {atm }}$, and $\mathrm{DRE}_{\text {netsurf }}$, respectively, for $\omega_{\text {aer }}$, and (iii) $11.81 \%, 0.24 \%$, and $3.72 \%$ for $\mathrm{DRE}_{\mathrm{TOA}}, \mathrm{DRE}_{\mathrm{atm}}$, and $\mathrm{DRE}_{\text {netsurf }}$, respectively, for $g_{\text {aer }}$.

The presented monthly mean aerosol DREs in this paper have been computed using monthly mean aerosol optical properties (AOD, $\omega_{\text {aer }}, g_{\text {aer }}$ ) in the RTM. This procedure induces some uncertainty because of the non-linear relationship between radiative fluxes, and hence DREs, and the input physical parameters of the RTM, meaning that monthly mean input-based "monthly mean fluxes" might not be the same as the monthly-mean fluxes averaged from hourly/daily fluxes. However, extensive comparisons between the monthly mean input-based "monthly mean fluxes", such as those used here, and monthly-mean fluxes averaged from daily fluxes, revealed a very good agreement (correlation coefficient equal to 0.985 ). Moreover, this problem is alleviated by the fact that the monthly mean model input data, e.g. ISCCP-D2 cloud properties, are based on a radiatively linear average method.

Furthermore, the use of monthly mean aerosol optical properties as input to the RTM, can also introduce uncertainty in monthly DRE calculations, because of the day by day variability of AOD, $\omega_{\text {aer }}$ and $g_{\text {aer. }}$. This DRE variability has been examined, based on estimated daily variabilities of AOD, $\omega_{\text {aer }}$, and $g_{\text {aer }}$, and applying the linear relationships derived in Sect. 4 (Fig. 7). This variability corresponds to the standard deviation of daily values, and is computed for every geographical cell (pixel) of the region, over the study period, i.e. 2000-2007, then it is averaged over all pixels. It has been calculated to be smaller than $60 \%$ for AOD, $25 \%$ for $\omega_{\text {aer }}$, and $12.5 \%$ for $g_{\text {aer }}$. Additional uncertainty of the model computed aerosol DREs is associated with the uncertainty of $\omega_{\text {aer }}$ model input data that are derived from the original GADS $\omega_{\text {aer }}$ data (see Sect. 2.2). Following the same method as above, i.e. using the derived relationship between $\Delta\left(\mathrm{DRE}_{\mathrm{i}}\right)$ and $\Delta\left(\omega_{\mathrm{aer}}\right)$, and given a value of $8 \%$, the estimated uncertainty of model DREs ranges from $29 \%$ (for $\left.\mathrm{DRE}_{\text {netsurf }}\right)$ to $59 \%$ for (DRE $\mathrm{atm}$ ).

The model aerosol DREs presented in this study are columnar and do not account for the vertical distribution of aerosol optical properties. Such information over the Mediterranean is available from ground-based lidar measurements (EARLINET, Bösenberg et al., 2003 and few other datasets, e.g. Gobbi et al., 2000; Di Iorio et al., 2009) which however do not ensure the complete spatial coverage required in the present study. Vertically distributed aerosol information for the entire Mediterranean basin has been made available recently from CALIOP instrument onboard the CALIPSO satellite (Winker et al., 2006). Nevertheless, this information is not yet extensively validated, and does not provide all three model input aerosol optical properties, i.e. AOD, $\omega_{\text {aer }}$, and $g_{\text {aer }}$. Furthermore, Because of the relatively small swath of CALIOP $(64 \mathrm{~km} \times 64 \mathrm{~km})$ these data are more limited spatially and temporally than MODIS, and thus provide probably inadequate coverage for our study. 
Nevertheless, in order to preliminary assess the uncertainties introduced by the use of columnar instead of vertically changing aerosol properties in our RTM, we performed a series of sensitivity tests, in which the RTM input aerosol properties changed with height. In a first step, we assessed the uncertainty of model computed DREs $\left(\mathrm{DRE}_{\mathrm{TOA}}, \mathrm{DRE}_{\mathrm{atm}}\right.$, and $\mathrm{DRE}_{\text {netsurf }}$ ) to changing AOD with height. This is because among AOD, $\omega_{\text {aer }}$, and $g_{\text {aer }}$, relevant and homogeneous vertically resolved information over the Mediterranean basin is available only for AOD, from recent satellite lidar measurements (CALIOP/CALIPSO). Limited information on changing aerosol $\omega_{\text {aer }}$ with height is available from sporadic measurements in specific Mediterranean sites, whereas no relevant information is available on $g_{\text {aer }}$. Moreover, according to the existing literature, aerosol loading (mass) is the aerosol property that changes more drastically with height than others. The RTM sensitivities were performed running the RTM using: (i) columnar integrated AOD values (as done in the original paper), and (ii) AOD vertical profiles, i.e. AOD values for 40 layers in the atmosphere extending from the surface, constrained by topography, up to TOA. The AOD data were taken from the Cloud-Aerosol Lidar with Orthogonal Polarization (CALIOP Level 2-Version 3.01) instrument onboard the CALIPSO satellite (launched in April 2006, Winker et al., 2007). The RTM was run for 4 geographical cells, representative of different aerosol types prevailing over the Mediterranean basin. The four cells, whose altitudes range from $90 \mathrm{~m}$ to $350 \mathrm{~m}$, are centered at: (i) $38.75^{\circ} \mathrm{N}, 23.75^{\circ} \mathrm{E}$, including Athens (Greece), corresponding to urban aerosol, (ii) $31.25^{\circ} \mathrm{N}, 6.25^{\circ} \mathrm{E}$, in Algerian desert (north Africa), corresponding to dust aerosol, (iii) $38.75^{\circ} \mathrm{N}$, $8.75^{\circ} \mathrm{E}$, in the western Mediterranean Sea, corresponding to maritime aerosol and (iv) $46.25^{\circ} \mathrm{N}, 21.25^{\circ} \mathrm{E}$, in the Romanian plains, corresponding to continental aerosol. The runs of RTM were performed for July 2007 in order to ensure overlapping between the CALIOP AOD availability and our study period. They provide at the same time an upper bound limit of uncertainties, since, as shown in our study (e.g. Fig. 5), DRE values are maximum in summer. The results reveal that taking into account the vertical distribution of AOD in the RTM modifies aerosol DREs by amounts ranging from about -2 to $2 \mathrm{~W} \mathrm{~m}^{-2}$, depending on the aerosol component and type. In general, the largest differences are calculated for marine and rural (continental) aerosols. Especially, in terms of DRE $\mathrm{T}_{\mathrm{TOA}}$, rural aerosol is found to be most sensitive to the vertical variation of AOD, with a change equal to $1.9 \mathrm{~W} \mathrm{~m}^{-2}$. At the surface ( $\mathrm{DRE}_{\text {surf }}$ and $\left.\mathrm{DRE}_{\text {netsurf }}\right)$ the largest sensitivity is found for maritime aerosol, with DRE undergoing changes equal to $0.4 \mathrm{~W} \mathrm{~m}^{-2}$. The percent differences (not shown) vary between -5 and $3 \%$. In conclusion, using columnar instead of vertically distributed AOD values in the RTM, introduces relatively small uncertainties in the computed aerosol direct radiative effects, with magnitudes smaller than $2 \mathrm{~W} \mathrm{~m}^{-2}(5 \%)$. Preliminary results of corresponding model sensitivity tests performed using constant and changing $\omega_{\text {aer }}$ values with height, also revealed changes of aerosol DRE components being smaller than $2.6 \mathrm{~W} \mathrm{~m}{ }^{-2}$ or $2.8 \%$.

\section{Conclusions}

In this study, a detailed spectral radiative transfer model along with spectral aerosol optical properties from MODIS and other satellite and reanalysis datasets have been used to compute the direct radiative effect of natural plus anthropogenic aerosols on the solar radiation budget of the climatically sensitive Mediterranean basin. To our knowledge this is the first study that focuses on the entire Mediterranean and computes separately all aerosol effects, DREs, namely on the outgoing SW radiation at TOA, DRE $\mathrm{TOA}_{\mathrm{T}}$, on solar atmospheric absorption, DRE $\mathrm{atm}_{\mathrm{a}}$, and on the downward, $\mathrm{DRE}_{\text {surf }}$, and absorbed SW radiation, DRE $\mathrm{netsurf}_{\text {, at surface. }}$ The model computations are performed under both all-sky and clear-sky conditions, using realistic data for all surface and atmospheric parameters, for the 7-yr period 2000-2007. The computed aerosol DREs are validated by thorough comparisons against reference measurements of SW fluxes from surface stations (Global Energy Balance Archive, GEBA).

Aerosols are found to modify significantly the regional solar radiation budget. During the studied 7-yr period aerosols increase the SW reflection back to space above the broader Mediterranean basin by $2.4 \mathrm{~W} \mathrm{~m}^{-2}$ under all-sky conditions and $4.5 \mathrm{~W} \mathrm{~m}^{-2}$ under clear-sky conditions, thus producing a planetary cooling over the region. These results are in reasonable agreement with similar estimates, ranging from -3 to $-0.5 \mathrm{~W} \mathrm{~m}^{-2}$ for all-sky and from -5 to $-1 \mathrm{~W} \mathrm{~m}^{-2}$ for clear-sky conditions, obtained by global climate and general circulations models (Takemura et al., 2002; Schulz et al., 2006). The Mediterranean atmosphere is heated by aerosols due to enhanced solar absorption by $11.1 \mathrm{~W} \mathrm{~m}^{-2}$ $\left(14.3 \mathrm{~W} \mathrm{~m}^{-2}\right.$ in clear-skies) whereas the surface is cooled by aerosols through reduced reception at surface $\left(16.5 \mathrm{~W} \mathrm{~m}^{-2}\right.$ all-sky, $22.9 \mathrm{~W} \mathrm{~m}^{-2}$ clear-sky) and subsequent absorption (13.5 W m${ }^{-2}$ all-sky, $18.8 \mathrm{~W} \mathrm{~m}^{-2}$ clear-sky). Even larger DREs are computed on a seasonal basis, reaching 26.2 and $31.7 \mathrm{~W} \mathrm{~m}^{-2}$ in case of all-sky and clear-sky DRE $\mathrm{Surf}_{\text {sur }}$, respectively. The maximum absolute DRE values are computed for summer (July) and the minimum ones for winter (December). However, under clear-sky conditions secondary DRE maxima appear in spring (April) in line with a corresponding spring AOD maximum. According to our results, the seasonal variation of aerosol direct radiative effects is primarily driven by the available solar radiation fluxes under both clear- and all-sky conditions. The role of aerosol loading, i.e. AOD, is important mostly in cloudless skies.

High aerosol absolute DRE values, locally exceeding $100 \mathrm{~W} \mathrm{~m}^{-2}$, are computed and show a north-to-south gradient, with the highest values over the deserts of northern Africa and Middle-East. Also, relatively high values are 
calculated over central and northern Europe, associated with anthropogenic aerosol emissions. In general, the largest DRE values are found in spring and summer throughout the entire Mediterranean basin, indicating thus the role of AOD and incoming solar radiation in determining the magnitude of their DRE values. If we exclude TOA, during winter and spring the largest DREs are computed over the eastern Mediterranean, while in summer and autumn there is not a uniform domination of eastern/central/western Mediterranean in terms of $\mathrm{DRE}_{\mathrm{atm}}$, DRE $\mathrm{D}_{\text {surf }}$, and $\mathrm{DRE}_{\text {netsurf val- }}$ ues. As for $\mathrm{DRE}_{\mathrm{TOA}}$, its largest values are generally observed over central Mediterranean. Hence, our results indicate significant spatial, apart from the seasonal, variability of aerosol radiative effects within the Mediterranean basin. The $2.5^{\circ} \times 2.5^{\circ}$ pixel-level $\mathrm{DRE}_{\mathrm{TOA}}$ values range between -7 and $25 \mathrm{~W} \mathrm{~m}^{-2}$. Positive values, indicating planetary warming, are computed for over North Africa and Middle-East, where absorbing dust is trapping SW radiation. The same phenomenon, though much weaker, occurs over the Alps due to the presence of pollution aerosol over snow, throughout the year except summer. The geographical patterns of DREs in the atmosphere and at surface are similar, with the largest values over deserts extending from Sahara up to Middle-East and the Anatolian peninsula.

Aerosols over the Mediterranean basin have a strong absorbing character. This is reflected on the estimated regional values of the ratio of DREs at TOA (DRE $\mathrm{DTA}_{\mathrm{TO}}$ ) and at surface (DRE $E_{\text {netsurf }}$ ) that vary between 0.09 and 0.27 throughout the year. Higher ratios $\mathrm{DRE}_{\mathrm{TOA}} / \mathrm{DRE}_{\text {netsurf }}$ are found over the Mediterranean Sea (0.35-0.5) and the Atlantic Ocean (0.45$0.75)$ than over European and African continents (0.05$0.45)$. This indicates the presence of significantly scattering aerosols (sea-salt) over oceanic areas against more absorbing aerosols, natural or anthropogenic, above continental regions. Yet, the smaller ratios $\mathrm{DRE}_{\mathrm{TOA}} / \mathrm{DRE}_{\text {netsurf }}$ above the Mediterranean Sea than the Atlantic Ocean point to the increased background of absorbing natural or/and anthropogenic aerosols (dust or/and black carbon) over the Mediterranean Sea. The computed DRE $\mathrm{E}_{\text {atm }}$ highlights the existence of a significant aerosol effect on thermal dynamics over the Mediterranean basin. The strong surface SW cooling for the region, estimated equal to $-13.5 \mathrm{~W} \mathrm{~m}^{-2}$ on annual basis, combined with an equally strong warming of the atmospheric column $\left(11 \mathrm{~W} \mathrm{~m}^{-2}\right)$, can modify the vertical atmospheric temperature lapse rate and atmospheric conditions, affecting the atmospheric circulation, cloud and precipitation formation. Such consequences, which are far more complex since they also critically depend on aerosol induced changes in temperature lapse rates and stability varying with altitude, can be important in the context of threatening desertification processes occurring in the Mediterranean (IPCC, 2007).

Our model results indicate the existence of inter-annual variations in aerosol DREs and associated solar fluxes over the period 2000-2007. Thus, the magnitude of DRE $E_{\text {netsurf }}$ has decreased by $18.4 \%$, mainly due to decreasing aerosol load- ings (AOD), inducing an increase in solar radiation absorbed at the surface of the Mediterranean basin. However, this has been overwhelmed by changes in other than aerosol parameters, which are relevant to solar radiation, primarily cloudiness, that yielded an overall decrease of the regional surface solar radiation by $25 \mathrm{~W} \mathrm{~m}^{-2}$.

According to model sensitivity tests, subject to equal percent modifications in aerosol properties, aerosol DRE is found to be mostly sensitive to aerosol single scattering albedo. Nevertheless, for realistic modifications in aerosol optical properties, i.e. within the range of observed natural or anthropogenic variability, AOD seems to be the main responsible parameter for modifications of aerosol radiative effects. Changes of DREs ( $\triangle \mathrm{DREs})$ are found to depend quasi-linearly on the changes in aerosol optical properties (AOD, $\left.\omega_{\text {aer }}, g_{\text {aer }}\right)$. The obtained relationships enable a first estimate of the expected consequences from actions aiming to reduce aerosol emissions (e.g. Air Framework Directive or Clean Air for Europe Programme). Future reductions in anthropogenic aerosol loadings in the Mediterranean basin of the order of $10 \%$ that could result from such actions may reduce aerosol radiative effects up to about $10 \%$, producing an increase of surface solar radiation mainly in summer, and hence surface heating, and a cooling of the atmospheric column owing to decreased aerosol solar absorption.

Uncertainties associated with model computations of aerosol DREs given in the present study arise from uncertainties in MODIS satellite retrievals used as model input aerosol optical properties, or they are induced by the use of monthly mean aerosol optical properties (AOD, $\left.\omega_{\text {aer }}, g_{\text {aer }}\right)$ in the RTM. Further uncertainty is also produced by the columnar nature of model DREs that neglect the vertical distribution of aerosol optical properties. These uncertainties associated with the model computed aerosol DREs have been thoroughly evaluated here and were found to be smaller than $10 \%$ in most cases, except for $\omega_{\text {aer }}$.

\section{Supplementary material related to this article is available online at: http://www.atmos-chem-phys.net/12/ 7165/2012/acp-12-7165-2012-supplement.pdf.}

Acknowledgements. CDP has been supported by a PENED 2003 $\mathrm{PhD}$ grant at early stages of this study. MK and NM acknowledge support by the PEGASOS project funded by the European Commission (FP7-ENV-2010-265148). The authors would like to thank the NASA-US for making available the Collection 005 and 5.1 Level-3 mean daily spectral aerosol data from MODIS instrument onboard-Terra and Aqua satellites. The ISCCP-D2 data were obtained from the NASA Langley Research Center (LaRC) Atmospheric Sciences Data Center (ASDC). The NCEP/NCAR Global Reanalysis Project data were obtained from the National Oceanic and Atmospheric Administration (NOAA) Cooperative Institute for Research in Environmental Sciences (CIRES) Climate 
Diagnostics Center, Boulder, Colorado, USA. The GEBA data were obtained from the GEBA database of the World Climate Program Water (WMO/ICSU) at ETH. The GADS data were obtained from the Meteorological Institute of the University of Munich, Germany (http://www.meteo.physik.uni-muenchen.de/strahlung/aerosol/ aerosol.htm). Authors thank the principal investigators and their staff for establishing and maintaining the AERONET sites used in this investigation. The authors also thank CALIPSO Science Team for their efforts in making data products publicly available. CALIOP data were obtained from the Atmospheric Science Data Center (ASDC) of NASA Langley Research Center.

Edited by: F. Dentener

\section{References}

Anderson, T. L., Charlson, R. J. Bellouin, N., Boucher, O., Chin, M., Christopher, S. A., Haywood, J., Kaufman, Y. J., Kinne, S., Ogren, J. A., Remer, L. A., Takemura, T., Tanré, D., Torres, O., Trepte, C. A., Wielicki, B. A., Winker, D. M., and Yu, H.: ATrain strategy for quantifying direct climate forcing by anthropogenic aerosols, B. Am. Meteorol. Soc., 86, 1795-1809, 2005.

Balis, D. S., Amiridis, V., Zerefos, C., Kazantzidis, A., Kazadzis, S., Bais, A. F., Meleti, C., Gerasopoulos, E., Papayannis, A., Matthias, V., Dier, H., and Andreae, M. O.: Study of the effect of different type of aerosols on UV-B radiation from measurements during EARLINET, Atmos. Chem. Phys., 4, 307-321, doi:10.5194/acp-4-307-2004, 2004.

Barnaba, F. and Gobbi, G. P.: Aerosol seasonal variability over the Mediterranean region and relative impact of maritime, continental and Saharan dust particles over the basin from MODIS data in the year 2001, Atmos. Chem. Phys., 4, 2367-2391, doi:10.5194/acp-4-2367-2004, 2004.

Benas, N., Hatzianastassiou, N., Matsoukas, C., Fotiadi, A., Mihalopoulos, N., and Vardavas, I.: Aerosol shortwave direct radiative effect and forcing based on MODIS Level 2 data in the Eastern Mediterranean (Crete), Atmos. Chem. Phys., 11, 1264712662, doi:10.5194/acp-11-12647-2011, 2011.

Bergamo, A., Tafuro, A. M., Kinne, S., De Tomasi, F., and Perrone, M. R.: Monthly-averaged anthropogenic aerosol direct radiative forcing over the Mediterranean based on AERONET aerosol properties, Atmos. Chem. Phys., 8, 6995-7014, doi:10.5194/acp8-6995-2008, 2008.

Bösenberg, J. and Matthias, V. J.: EARLINET: A European Aerosol Research Lidar Network to Establish an Aerosol Climatology, Max-Planck-Institut Report No. 348, 2003.

Chin, M., Ginoux, P., Kine, S., Torres, O., Holben, B. N., Duncan, B. N., Martin, R. V., Logan, J. A., Higurashi, A., and Nakajima, T.: Tropospheric aerosol optical thickness from the GOCART model and comparisons with satellite and Sun photometer measurements, J. Atmos. Sci., 59, 461-483, 2002.

Charlson, R., Schwartz, S., Hales, J., Cess, R., Coakley Jr., R. J., Hansen, J., and Hofmann, D.: Climate forcing by anthropogenic aerosols, Science, 255, 423-430, 1992.

Christopher, A. and Jones, T.: Short-wave aerosol radiative efficiency over the global oceans derived from satellite data. Tellus B, 60, 636-640, 2008.

Chu, D. A., Kaufman, Y. J., Ichoku, C., Remer, L. A., Tanre, D., and Holben, B. N.: Validation of MODIS aerosol opti- cal depth retrieval over land. Geophys. Res. Lett., 29, 8007, doi:10.1029/2001GL013205, 2002.

Chung, C. E., Ramanathan, V., Kim, D., and Podgorny, I. A.: Global anthropogenic aerosol direct forcing derived from satellite and groundbased observations, J. Geophys. Res., 110, D24207, doi:10.1029/2005JD006356, 2005.

Di Biagio, C., di Sarra, A., Meloni, D., Monteleone, F., Piacentino, S., and Sferlazzo, D.: Measurements of Mediterranean aerosol radiative forcing and influence of the single scattering albedo, J. Geophys. Res., 114, D06211, doi:10.1029/2008JD011037, 2009.

Di Biagio, C., di Sarra, A., and Meloni, D.: Large atmospheric shortwave radiative forcing by Mediterranean aerosols derived from simultaneous ground-based and spaceborne observations and dependence on the aerosol type and single scattering albedo, J. Geophys. Res., 115, D10209, doi:10.1029/2009JD012697, 2010.

Di Iorio, T., di Sarra, A., Sferlazzo, D. M., Cacciani, M., Meloni, D., Monteleone, F., Fuà, D., and Fiocco, G.: Seasonal evolution of the tropospheric aerosol vertical profile in the central Mediterranean and role of desert dust, J. Geophys. Res., 114, D02201, doi:10.1029/2008JD010593, 2009.

di Sarra, A., Di Iorio, T., Cacciani, M., Fiocco, G., and Fua, D.: Saharan dust profiles measured by lidar from Lampedusa, J. Geophys. Res., 106, 10335-10347, doi:10.1029/2000JD900734, 2001.

di Sarra, A., Pace, G., Meloni, D., De Silvestri, L., Piacentino, S., and Monteleone, F.: Surface shortwave radiative forcing of different aerosol types in the Mediterranean, Geophys. Res. Lett., 35, L02714, doi:10.1029/2007GL032395, 2008.

Formenti, P., Reiner, O., Sprung, D., Andreae, M. O., Wendisch, M., Wex, H., Kindred, D., Dewey, K., Kent, J., Tzortziou, M., Vasaras, A., and Zerefos, C.: The STAAARTE-MED 1998 summer airborne measurements over the Aegean Sea: 1. Aerosol particles and trace gases, J. Geophys. Res., 107, 4450, doi:10.1029/2001JD001337, 2002

Forster, P., Ramaswamy, V., Artaxo, P., Berntsen, T., Betts, R., Fahey, D. W., Haywood J., Lean, J., Lowe, D. C., Myhre, G., Nganga, J., Prinn, R., Raga, G., Schulz, M., Van Dorland, R.: Changes in atmospheric constituents and in radiative forcing, in Climate Change 2007: The Physical Science Basis - Contribution of Working Group I to the Fourth Assessment Report of the Intergovernmental Panel on Climate Change, edited by: Solomon, S., Qin, D., Manning, M., Chen, Z., Marquis, M., Averyt, K. B., Tignor, M., and Miller, H. L., 289-348, Cambridge Univ. Press, New York, USA, 2007.

Gerasopoulos, E., Kouvarakis, G., Babasakalis, P., Vrekoussis, M., Putaud, J. P., and Mihalopoulos, N.: Origin and variability of particulate matter $\left(\mathrm{PM}_{10}\right)$ mass concentrations over the Eastern Mediterranean, Atmos. Environ., 40, 4679-4690, 2006.

Gilgen H. and Ohmura A.: The Global Energy Balance Archive, B. Am. Meteor. Soc., 80, 831-850, 1999.

Hansen, J., Sato, M., and Ruedy, R.: Radiative forcing and climate response, J. Geophys. Res. 102, 6831-6864 1997.

Hatzianastassiou, N. and Vardavas, I.: Shortwave radiation budget of the Northern Hemisphere using International Satellite Cloud Climatology Project and NCEP/NCAR climatological data, J. Geophys. Res., 104, 24401-24421, 1999.

Hatzianastassiou, N. and Vardavas, I.: Shortwave radiation budget of the Southern Hemisphere using ISCCP C2 and NCEP/NCAR 
climatological data, J. Clim., 14, 4319-4329, 2001.

Hatzianastassiou, N., Katsoulis, B., and Vardavas, I.: Global distribution of aerosol direct radiative forcing in the ultraviolet and visible arising under clear skies, Tellus, 56B, 51-71, 2004a.

Hatzianastassiou, N., Katsoulis, B., and Vardavas, I.: Sensitivity analysis of aerosol direct radiative forcing in ultraviolet-visible wavelengths and consequences for the heat budget, Tellus, 56B, 368-381, 2004b.

Hatzianastassiou, N., Fotiadi, A., Matsoukas, Ch., Pavlakis, K., Drakakis, E., Hatzidimitriou, D., and Vardavas, I.: Long-term global distribution of earth's shortwave radiation budget at the top of atmosphere, Atmos. Chem. Phys., 4, 1217-1235, doi:10.5194/acp-4-1217-2004, 2004c.

Hatzianastassiou, N., Matsoukas, C., Fotiadi, A., Pavlakis, K. G., Drakakis, E., Hatzidimitriou, D., and Vardavas, I.: Global distribution of Earth's surface shortwave radiation budget, Atmos. Chem. Phys., 5, 2847-2867, doi:10.5194/acp-5-2847-2005, 2005.

Hatzianastassiou, N., Matsoukas, C., Drakakis, E., Stackhouse Jr., P. W., Koepke, P., Fotiadi, A., Pavlakis, K. G., and Vardavas, I.: The direct effect of aerosols on solar radiation based on satellite observations, reanalysis datasets, and spectral aerosol optical properties from Global Aerosol Data Set (GADS), Atmos. Chem. Phys., 7, 2585-2599, doi:10.5194/acp-7-2585-2007, 2007a.

Hatzianastassiou, N., Matsoukas, C., Fotiadi, A., Stackhouse Jr., P. W., Koepke, P., Pavlakis, K. G., and Vardavas, I.: Modelling the direct effect of aerosols in the solar near-infrared on a planetary scale, Atmos. Chem. Phys., 7, 3211-3229, doi:10.5194/acp-73211-2007, 2007b.

Hatzianastassiou, N., Gkikas, A., Mihalopoulos, N., Torres, O., Katsoulis, B. D.: Natural versus anthropogenic aerosols in the eastern Mediterranean basin derived from multiyear TOMS and MODIS satellite data, J. Geophysical Research., 114, D24202, doi:10.1029/2009JD011982, 2009.

Haywood, J., Francis, P., Osborne, S., Glew, M., Loeb, N., Highwood, E., Tanre, D., Myhre, G., Formenti, P., and Hirst, E.: Radiative properties and direct radiative effect of Saharan dust measured by the C-130 aircraft during SHADE: 1 . Solar spectrum, J. Geophys. Res., 108, 8577, doi:10.1029/2002JD002687, 2003.

Haywood, J. M. and Shine, K. P.: Multi-spectral calculations of the radiative forcing of tropospheric sulphate and soot aerosols using a column model, Q. J. Roy. Meteor. Soc., 123, 1907-1930, 1997.

Haywood, J. M. and Ramaswamy, V.: Global sensitivity studies of the direct radiative forcing due to anthropogenic sulfate and black carbon aerosols, J. Geophys. Res., 103, 6043-6058, 1998.

Hess, M., Koepke, P., and Schult, I.: Optical properties of aerosols and clouds: The software package OPAC, B. Am. Meteor. Soc., 79, 831-844, 1998.

Hodzic, A., Madronich, S., Bohn, B., Massie, S., Menut, L., and Wiedinmyer, C.: Wildfire particulate matter in Europe during summer 2003: meso-scale modeling of smoke emissions, transport and radiative effects, Atmos. Chem. Phys., 7, 4043-4064, doi:10.5194/acp-7-4043-2007, 2007.

Hsu, N. C., Tsay, S. C., King, M. D., and Herman, J. R.: Aerosol properties over bright-reflecting source regions, IEEE Trans. Geosci. Remote Sens., 42, 557-569, 2004.

Intergovernmental Panel on Climate Change (IPCC): Climate Change 2007: The Physical Science Basis. Summary for Policymakers, Paris, February 2007.
Israelevich, P. L., Levin, Z., Joseph, J. H., and Ganor, E.: Desert aerosol transport in the Mediterranean region as inferred from the TOMS aerosol index, J. Geophys. Res., 107, 4572, doi:10.1029/2001JD002011, 2002.

Kalivitis, N., Gerasopoulos, E., Vrekoussis, M., Kouvarakis, G., Kubilay, N., Hatzianastassiou, N., Vardavas, I., and Mihalopoulos, N.: Dust transport over the Eastern Mediterranean derived from TOMS, AERONET and surface measurements, J. Geophys. Res., 112, D03202, doi:10.1029/2006JD007510, 2007.

Kallos, G., Astitha, M., Katsafados, P., and Spyrou, C.: Long-range transport of anthropogenically and naturally produced particulate matter in the Mediterranean and North Atlantic: Current state of knowledge, J. Appl. Meteorol. Climatol., 46, 1230-1251, doi:10.1175/JAM2530.1, 2007.

Kalnay, E., Kanamitsu, M., Kistler, R., Collins, W., Deaven, D., Gandin, L., Iredell, M., Saha, S., White, G., Woollen, J., Zhu, Y., Chelliah, M., Ebisuzaki, W., Higgins, W., Janowiak, J., Mo, K. C., Ropelewski, C., Wang, J., Leetmaa, A., Reynolds, R., Jenne, R., and Joseph, D.: The NCEP/NCAR 40-Year Reanalysis Project, B. Am. Meteor. Soc., 77, 437-471, 1996.

Kanakidou, M., Mihalopoulos, N., Kindap, T., Im, U., Vrekoussis, M., Gerasopoulos, E., Dermitzaki, E., Unal, A., Kocak, M., Markakis, K., Melas, D., Kouvarakis, G., Youssef, A. F., Richter, A., Hatzianastassiou, N., Hilboll, A., Ebojie, F., von Savigny, C., Ladstaetter-Weissenmayer, A., Burrows, J., and Moubasher, H.: Megacities as hot spots of air pollution in the East Mediterranean. Atmos. Environ., 45, 1223-1235, 2011.

Kaufman, Y. J., Tanré, D., Remer, L. A., Vermote, E. F., Chu, A., and Holben, B. N.: Operational remote sensing of tropospheric aerosol over land from EOS Moderate-resolution Imaging Spectroradiometer, J. Geophys. Res., 102, 17051-17065, 1997.

Kaufman, Y. J., Tanré, D., and Boucher, O.: A satellite view of aerosols in the climate system, Nature, 419, 215-223, doi:10.1038/nature01091, 2002.

Kazadzis, S., Kouremeti, N., Bais, A., Kazantzidis, A., and Meleti, C.: Aerosol forcing efficiency in the UVA region from spectral solar irradiance measurements at an urban environment, Ann. Geophys., 27, 2515-2522, doi:10.5194/angeo-27-25152009, 2009.

Kiehl, J. T. and Trenberth, K. E.: Earth's annual global mean energy budget, B. Am. Meteorol. Soc., 78, 197-208, 1997.

King, M. D., Kaufman, Y. J., Tanré, D., and Nakajima, T.: Remote sensing of tropospheric aerosols from space: Past, present, and future, B. Am. Meteor. Soc., 80, 2229-2259, 1999.

King, M. D., Menzel, W. P., Kaufman, Y. J., Tanre, D., Gao, B. C., Platnick, S., Ackerman, S. A., Remer, L. A., Pincus, R., and Hubanks, P. A.: Cloud and aerosol properties, precipitable water, and profiles of temperature and humidity from MODIS, IEEE Trans. Geosci. Remote Sens., 41, 442-458, doi:10.1109/TGRS.2002.808226, 2003.

Kinne, S., Lohmann, U., Feichter, J., Schulz, M., Timmreck, C., Ghan, S., Easter, R., Chin, M., Ginoux, P., Takemura, T., Tegen, I., Koch, D., Herzog, M., Penner, J., Pitari, G., Holben, B., Eck, T., Smirnov, A., Dubovik, O., Slutsker, I., Tanre, D., Torres, O., Mishchenko, M., Geogdzhayev, I., Chu, D. A., and Kaufman, Y.: Monthly averages of aerosol properties: A global comparison among models, satellite data, and AERONET ground data, J. Geophys. Res., 108, 4634, doi:10.1029/2001JD001253, 2003. 
Kistler, R., Kalnay, E., Collins, W., Saha, S., White, G., Woollen, J., Chelliah, M., Ebisuzaki, W., Kanamitsu, M., Kousky, V., van den Dool, H., Jenne, R., and Fiorino, M.: The NCEP-NCAR 50 yr reanalysis: Monthly means CD-ROM and documentation, B. Am. Meteorol. Soc., 82, 247-267, 2001.

Koepke, P. and Hess, M.: Scattering functions of tropospheric aerosols: The effect of nonspherical particles, Appl. Opt., 27, 2422-2430, 1988.

Koepke, P., Hess, M., Schult, I., and Shettle, E. P.: Global Aerosol Data Set. Report no 243, Max-Planck Institut für Meteorologie, Hamburg, Germany, 44 pp., 1997.

Koukouli, M. E., Kazadzis, S., Amiridis, V., Ichoku, C., Balis, D. S., Bais, A. F.: Signs Of A Negative Trend In The MODIS Aerosol Optical Depth Over The Southern Balkans, Atmos. Environ., 44, 1219-1228, 2010.

Law, K. S. and Stohl, A.: Arctic Air Pollution: Origins and Impacts, Science, 315, 1537-1540, doi:10.1126/science.1137695, 2007.

Lelieveld, J., Berresheim, H., Borrmann, S., Crutzen, P. J., Dentener, F. J., Fischer, H. Feichter, J., Flatau, P. J., Heland, J., Holzinger, R., Korrmann, R., Lawrence, M. G., Levin, Z., Markowicz, K. M., Mihalopoulos, N., Minikin, A., Ramanathan, V., de Reus, M., Roelofs, G. J., Scheeren, H. A., Sciare, J., Schlager, H., Schultz, M., Siegmund, P., Steil, B., Stephanou, E. G., Stier, P., Traub,M., Warneke, C., Williams, J., and Ziereis, H.: Global air pollution crossroads over the Mediterranean, Science, 298, 794-799, 2002.

Levy, R. C., Remer, L. A., Mattoo, S., Vermote, E. F., and Kaufman, Y. J.: Second-generation operational algorithm: Retrieval of aerosol properties over land from inversion of Moderate Resolution Imaging Spectroradiometer spectral reflectance, J. Geophys. Res., 112, D13211, doi:10.1029/2006JD007811, 2007.

Lyamani, H., Olmo, F. J., Alcañtara, A., and Alados-Arboledas, L.: Atmospheric aerosols during the 2003 heat wave in southeastern Spain. I: Spectral optical depth, Atmos. Environ., 40, 6453-6464, doi:10.1016/j.atmosenv.2006.04.048, 2006.

Markowicz, K. M., Flatau, P. J., Ramana, M. V., Crutzen, P. J., and Ramanathan, V.: Absorbing Mediterranean aerosols lead to a large reduction in the solar radiation at the surface, Geophys. Res. Lett., 29, 1968, doi:10.1029/2002GL015767, 2002.

Meloni, D., di Sarra, A., DeLuisi, J., Di Iorio, T., Fiocco, G., Junkermann, W., and Pace, G.: Tropospheric aerosols in the Mediterranean: 2. Radiative effects through model simulations and measurements, J. Geophys. Res., 108, 4317, doi:10.1029/2002JD002807, 2003.

Meloni, D., di Sarra, A., Biavati, G., DeLuisi, J. J., Monteleone, F., Pace, G., Piacentino, S., and Sferlazzo, D.: Seasonal behavior of Saharan dust events at the Mediterranean island of Lampedusa in the period 1999-2005, Atmos. Environ., 41, 3041-3056, 2007.

Mishchenko, M. I., Geogdzhayev, I. V., Rossow, W. B., Cairns, B., Carlson, B. E., Lacis, A. A., Liu, L., and Travis, L. D.: Long-term satellite record reveals likely recent aerosol trend, Science, 315, 1543, doi:10.1126/science.1136709, 2007.

Morcrette, J. J.: The surface downward longwave radiation in the ECMWF forecast system, J. Climate, 15, 1875-1992, 2002.

Moulin, C., Lambert, C., Dayan, U., Masson, V., Ramonet, M., Bousquet, P., Legrand, M., Balkanski, Y., Guelle, W., Marticorena, B., Bergametti, G., and Dulac, F.: Satellite climatology of African dust transport in the Mediterranean atmosphere, J. Geophys. Res., 103, 13137-13144, 1998.
Myhre, G., Stordal, F., Restad, K., and Isaksen, I. S. A.: Estimation of the direct radiative forcing due to sulfate and soot aerosols, Tellus 50B, 463-477, 1998.

Pace, G., di Sarra, A., Meloni, D., Piacentino, S., and Chamard, P.: Aerosol optical properties at Lampedusa (Central Mediterranean). 1. Influence of transport and identification of different aerosol types, Atmos. Chem. Phys., 6, 697-713, doi:10.5194/acp-6-697-2006, 2006.

Papadimas C. D., Hatzianastassiou, N., Mihalopoulos, N., Querol, X., Vardavas, I.: Spatial and temporal variability in aerosol properties over the Mediterranean basin based on $6 \mathrm{yr}$ (2000-2006) MODIS data, J. Geophys. Res., 113, D11205, doi:10.1029/2007JD009189, 2008.

Papadimas, C. D., Hatzianastassiou, N., Mihalopoulos, N., Kanakidou, M., Katsoulis, B. D., and Vardavas, I.: Assessment of the MODIS Collections C005 and C004 aerosol optical depth products over the Mediterranean basin, Atmos. Chem. Phys., 9, 29872999, doi:10.5194/acp-9-2987-2009, 2009.

Penner, J. E., Charlson, R. J., Hales, J. M., Laulainen, N. S., Leifer, R., Novakov, T., Ogren, J., Radke, L. F., Schwartz, S. E., and Travis, L.: Quantifying and minimizing uncertainty of climate forcing by anthropogenic aerosols, B. Am. Meteorol. Soc., 75, 375-400, 1994.

Penner, J. E., Chuang, C. C., and Grant, K.: Climate forcing by carbonaceous and sulfate aerosols, Clim. Dynam. 14, 839-851, 1998.

Pérez, N., Pey, J., Querol, X., Alastuey, A., López, J. M., and Viana, M.: Partitioning of Major and Trace Components in $\mathrm{PM}_{10^{-}}$ $\mathrm{PM}_{2.5}-\mathrm{PM}_{1}$ at an Urban Site in Southern Europe, Atmos. Environ., 42, 1677-1691, 2008.

Querol, X., Pey, J., Pandolfi, M., Alastuey, A., Cusack, M., Pérez, N., Moreno, T., Viana, N., Mihalopoulos, N., Kallos, G., and Kleanthous, S.: African dust contributions to mean ambient $\mathrm{PM}_{10}$ mass-levels across the Mediterranean basin, Atmos. Environ., 43, 4266-4277, 2009.

Quinn, P. K. and Bates, T. S.: Regional aerosol properties: Comparisons of boundary layer measurements from ACE 1, ACE 2, aerosols99, INDOEX, ACE asia, TARFOX, and NEAQS, J. Geophys. Res., 110, D14202, doi:10.1029/2004JD004755, 2005.

Ramanathan, V., Crutzen, P. J., Kiehl, J. L., and Rosenfeld, D.: Aerosols, climate, and the hydrological cycle, Science, 294, 2119-2124, 2001.

Remer, L. A., Tanré, D., Kaufman, Y. J., Ichoku, C., Mattoo, S., Levy, R., Chu, D. A., Holben, B., Dubovik, O., Smirnov, A., Martins, J. V., Li, R.-R., and Ahman, Z.: Validation of MODIS aerosol retrieval over ocean, Geophys. Res. Lett., 29, 8008, doi:10.1029/2001/GL013204, 2002.

Remer, L. A., Kaufman, Y. J.,Tanré, D., Mattoo, S. , Chu, D. A., Martins, J. V., Li R.-R., Ichoku, C., Levy, R. C., Kleidman, R. G., Eck, T. F., Vermote, E., and Holben, B. N.: The MODIS aerosol algorithm, products and validation, J. Atmos. Sci., 62, 947-973, 2005.

Remer, L. A., Kleidman, R. G., Levy, R. C., Tanré, D., Mattoo, S., Vanderlei Martins, J., Ichoku, Ch., Koren, I., Yu, H., and Holben, B. N: An emerging aerosol climatology from the MODIS satellite sensors, J. Geophys. Res., 113, D14S07, doi:10.1029/2007JD009661, 2008.

Rinke, A., Dethloff, K., and Fortmann, M.: Regional climate effects of Arctic Haze, Geophys. Res. Lett., 31, L16202, doi:10.1029/ 
2004GL020318, 2004.

Roger, J. C., M. Mallet, P. Dubuisson, H. Cachier, E. Vermote, O. Dubovik, and S. Despiau: A synergetic approach for estimating the local direct aerosol forcing: Application to an urban zone during the Expérience sur Site pour Contraindre les Modelès de Pollution et de Transport d'Emission (ESCOMPTE) experiment, J. Geophys. Res., 111, D13208, doi:10.1029/2005JD006361, 2006.

Rossow, W. B. and Schiffer, R. A.: Advances in understanding clouds from ISCCP, B. Am. Meteorol. Soc., 80, 2261-2287, 1999.

Rossow, W. B., Walker, A. W., Beuschel, D. E., and Roiter, M. D.: International Satellite Cloud Climatology Project (ISCCP). Documentation of new cloud datasets, 115 pp., Wold Meteorol. Org. Geneva, 1996.

Saha, A., Mallet, M., Roger, J. C., Dubuisson, P., Piazzola, J., and Despiau, S.: One year measurements of aerosol optical properties over an urban coastal site: Effect on local direct radiative forcing, Atmos. Res., 90, 195-202, doi:10.1016/j.atmosres.2008.02.003, 2008.

Santese, M., Perrone, M. R., Zakey, A. S., De Tomasi, F., and Giorgi, F.: Modeling of Saharan dust outbreaks over the Mediterranean by RegCM3: case studies, Atmos. Chem. Phys., 10, 133156, doi:10.5194/acp-10-133-2010, 2010.

Santos, D., Costa, M. J., and Silva, A. M.: Direct SW aerosol radiative forcing over Portugal, Atmos. Chem. Phys., 8, 5771-5786, doi:10.5194/acp-8-5771-2008, 2008.

Schulz, M., Textor, C., Kinne, S., Balkanski, Y., Bauer, S., Berntsen, T., Berglen, T., Boucher, O., Dentener, F., Guibert, S., Isaksen, I. S. A., Iversen, T., Koch, D., Kirkevåg, A., Liu, X., Montanaro, V., Myhre, G., Penner, J. E., Pitari, G., Reddy, S., Seland, $\varnothing$., Stier, P., and Takemura, T.: Radiative forcing by aerosols as derived from the AeroCom present-day and pre-industrial simulations, Atmos. Chem. Phys., 6, 5225-5246, doi:10.5194/acp-65225-2006, 2006.

Sciare, J., Bardouki, H., Moulin, C., and Mihalopoulos, N.: Aerosol sources and their contribution to the chemical composition of aerosols in the Eastern Mediterranean Sea during summertime, Atmos. Chem. Phys., 3, 291-302, doi:10.5194/acp-3-291-2003, 2003.

Schult, I., Feichter, J., and Cooke, W. F.: Effect of black carbon and sulfate aerosols on the global radiation budget, J. Geophys. Res., 102, 30107-30117, 1997.
Takemura, T., Nakajima, T., Dubovik, O., Holben, B. N., and Kinne, S.: Single-scattering albedo and radiative forcing of various aerosol species with a global three-dimensional model, J. Climate, 15, 333-352, 2002.

Tanré, D., Kaufman, Y. J., Herman, M., and Mattoo, S: Remote sensing of aerosol over oceans from EOS-MODIS, J. Geophys. Res. 102, 16971-16988, 1997.

Treffeisen, R., Rinke, A., Fortmann, M., Dethloff, K., Herber, A., and Yamanouchi, T.: A case study of the radiative effects of arctic aerosols in March 2000, Atmos. Environ, 39, 899-911, 2005.

Vardavas, I. and Carver, J. H.: Solar and terrestrial parameterizations for radiative convective models, Planet. Space Sci., 32, 1307-1325, 1984.

Vardavas, I. M. and Koutoulaki, K.: A model for the solar radiation budget of the Northern Hemisphere: Comparison with Earth Radiation Budget Experiment data, J. Geophys. Res., 100, 73037314, 1995.

Vardavas, I. M. and Taylor, F. W.: Radiation and Climate: Atmospheric energy budget from satellite remote sensing, International Series of Monographs on Physics No. 138, Oxford University Press, Oxford, 2011.

Vrekoussis, M., Liakakou, E., Kocak, M., Kubilay, N., Oikonomou, K., Sciare, J., and Mihalopoulos, N: Seasonal variability of optical properties of aerosols in the Eastern Mediterranean, Atmos. Environ., 39, 7083-7094, 2005.

Wild, M.: Global dimming and brightening: A review. Journal of Geophysical Research, 114, D00D16, doi:10.1029/2008JD011470, 2009.

Wild, M., Ohmura A., Gilgen H., and Roeckner E.: Validation of general circulation model radiative fluxes using surface observations, J. Clim., 8, 1309-1324, 1995.

Winker, D. M., C. A. Hostetler, M. A. Vaughan, and A. H. Omar: CALIOP algorithm theoretical basis document, Part 1: CALIOP instrument and algorithms overview, PC-SCI-202, Part 1, Release 2, September 2006.

Yu, H., Kaufman, Y. J., Chin, M., Feingold, G., Remer, L. A., Anderson, T. L., Balkanski, Y., Bellouin, N., Boucher, O., Christopher, S., DeCola, P., Kahn, R., Koch, D., Loeb, N., Reddy, M. S., Schulz, M., Takemura, T., and Zhou, M.: A review of measurement-based assessments of the aerosol direct radiative effect and forcing, Atmos. Chem. Phys., 6, 613-666, doi:10.5194/acp-6-613-2006, 2006. 